\title{
Study on Concrete Pier Impact Performance after Implementing Equal Cross-Section Stainless Steel with Protection from Closed-Cell Aluminum Foam
}

\author{
Xiwu Zhou $\mathbb{D}^{\text {, }}$, Honglong Zhang $\left(\mathbb{D}\right.$, Wenchao Zhang ${ }^{(}$, and Guoxue Zhang $\mathbb{D}$ \\ School of Transportation and Civil Engineering \& Architecture, Foshan University, Foshan, China \\ Correspondence should be addressed to Honglong Zhang; 1942516816@qq.com
}

Received 29 August 2020; Revised 15 September 2020; Accepted 29 September 2020; Published 15 October 2020

Academic Editor: Amr A. Nassr

Copyright (c) 2020 Xiwu Zhou et al. This is an open access article distributed under the Creative Commons Attribution License, which permits unrestricted use, distribution, and reproduction in any medium, provided the original work is properly cited.

\begin{abstract}
In the present study, in order to examine the impact performances of ordinary reinforced concrete bridge piers which have been replaced by stainless-steel bars of equal cross-sections under the protective condition of anticollision material, the impact dynamic responses of the ordinary reinforced concrete bridge piers, with replacements under the protection of closed-cell aluminum foam, were compared and analyzed using an ultrahigh drop hammer impact test system. The results showed that when the impact velocity was small (for example, less than $1.42 \mathrm{M} / \mathrm{s}$ ), after the implementation of equal cross-sectional replacements, the closed-cell aluminum foam had been in an elastic or yield stage. During that stage, the impact forces of the stainless-steel reinforced concrete piers were larger than those of the ordinary reinforced concrete piers, and the relative ratios were stable at approximately 28 to $34 \%$. In addition, the relative ratios of the displacements at the tops of the components were also found to be stable at approximately $22 \%$, and the change rates of the concrete ultrasonic damages were approximately the same. However, when the impact forces had increased (for example, more than $1.67 \mathrm{~m} / \mathrm{s}$ ), the closed-cell aluminum foam entered a densification stage, and the peak impact force ratios decreased sharply. It was also observed that the relative peak displacement ratios at the tops of the components displayed increasing trends, and the change rates of the concrete ultrasonic damages had displayed major flux. Therefore, the replacement of the ordinary piers with stainless-steel bars had increased the possibility of shear failures.
\end{abstract}

\section{Introduction}

In recent years, accidents involving ships colliding with bridges have frequently occurred and have seriously threatened the safety of people and property [1-3]. Due to the fact that stainless steel can improve the safety and durability of structures, an increasing number of the structural designs of the bridge have included stainless steel instead of ordinary steel. At the present time, more than 3,400 tons of stainless-steel bars have been implemented in China's Hong Kong-Zhuhai-Macao Bridge. The stainless-steel bars have been mainly used for the prefabricated pier body, tower base, bearing pad stone, bearing platform, and abutment, as well as other parts of the bridge. As an important load-bearing component of bridge structures, the impact resistance abilities of reinforced concrete $(\mathrm{RC})$ piers are very important to the overall safety of the concrete structures [4-6]. Although major achievements have been made in regard to the anticollision abilities of piers, and there have also been national standards put in place for the testing methods of anticollision devices, large numbers of RC piers still remain exposed to the risk of ship collisions due to failures in setting anticollision devices, or due to the fact that the distances between the anticollision devices and RC pier columns do not meet the requirements [7]. Currently, closed-cell aluminum foam is used as an anticollision device. Due to its advantages of light weight, high specific strength, and designable function, it has a wide range of applications in the field of impact protection $[8,9]$. Moreover, the use of closedcell aluminum foam as bridge pier protection material has widely concerned researchers in recent years and has gained practical engineering significance [10-12]. 
The current research regarding reinforced concrete members under impact loads in China and internationally mainly focuses on the following three aspects: theoretical analysis; experimental research; and numerical simulation. Kazunori Fujikake et al. of Japan [13] carried out lateral impact tests on reinforced concrete members which were simply supported at both ends. The results showed that the failure modes of the structures had varied under the different reinforcement ratios and impact energy, and a relationship was observed between the load and the midspan displacements. Tsang et al. [14], Sharma et al. [15], Abdelkarim and Elgawady [16], and Xiaoyu et al. [17] carried out static elastic-plastic analyses, theoretical analyses under impact loads, and numerical simulations. The results showed that the dynamic bearing capacities of the examined reinforced concrete columns undergoing vehicle impacts could potentially be significantly underestimated when using simple quasistatic analysis methods. Furthermore, the dynamic bearing capacities could be increased by approximately $15 \%$ by the strain rate effects. In the studies conducted by Zhou et al. [18], ordinary steel bars were replaced with stainlesssteel bars of equal strength under impact loads of the same energy, and the dynamic responses were compared. The test results showed that the change trends of the stainless-steel bars and the replaced ordinary steel bars of equal strength were the same in regard to the maximum impact force, strain of the steel bars, and the concrete and peak displacements. In addition, the relative ratios were within 5\% under the same impact energy. In another related study, Tian et al. [19] used LS-DYNA to examine the dynamic responses of reinforced concrete columns under the impacts of rigid spheres. The research results indicated that it was reasonable and effective to use separated models of bond slippages between reinforcement and concrete for numerical simulations. Huo and $\mathrm{Hu}$ [20] carried out a drop weight impact test on reinforced concrete beams and compared the results with those of a static load test to study the failure mechanism of concrete beams under impact load. The results showed that the cracks of concrete beams with bending failure under static load were mainly bending and bending shear cracks under lowspeed impact, and abdominal shear cracks under high-speed impact load. However, due to the better deformation and energy absorption characteristics of the closed-cell aluminum foam material, researchers in China and other countries have performed corresponding research. For example, Bozzolo and Pamini [21] studied the energy absorption characteristics of aluminum foam material. The results showed that, when the aluminum foam entered the yield stage, a longer yield platform had been generated. In addition, it was found that the longer the yield platform was, the stronger its energy consumption capacity would be. The previous studies conducted by Hangal et al. [22], Mondal [23], and Raj et al. [24] revealed the yield strength of closedcell aluminum foam, and it was observed that the yield strength had increased with increases in the relative density. In addition, the energy absorption capacity also increased and the densification strain decreased with increases in the relative density. Paul and Ramamurty [25] studied the strain rate efficiency of closed-cell aluminum foam through experiments. It was found that the plastic strength and energy absorption of closed-cell aluminum foam increased with the increase of strain rate. In addition, compared with the stress-strain curve of aluminum foam under quasistatic condition, it was found that the yield stress under dynamic loading was significantly higher than that in a quasistatic state. Klintworth and Stronge [26] analyzed the elasticplastic deformation of aluminum foam. The results show that the plastic deformation analysis value was higher than that of the foam material. Simone and Gibson [27] analyzed the influence of cell mass distribution, wrinkle, and bending on the stiffness and strength of foam metal materials by means of finite element simulation. The research results showed that the uneven distribution of cell wall mass, wrinkle, and bending were more important factors in the experimental value of stiffness and strength of foam metal material lower than the theoretical value calculated by the ideal model. Zhu [28] studied the protective measures of reinforced concrete columns under impact load and analyzed the anticollision effect of external application of aluminum foam protection measures. The results showed that the damage of structural columns protected by closed-cell aluminum foam was less significant than that of unprotected columns. Wu et al. [29], aiming at the high risk of the pier under the impact load of rolling stones, proposed a closed foam aluminum filling structure to protect the pier. It was concluded that wrapping the aluminum foam protection layer may prolong the impact time and reduce the impact load. At the same time, the influence of the thickness of the wrapping layer on the impact response of the pier was also discussed, and it was shown that the thickness of the foam aluminum was appropriately increased to reduce the impact response of the pier, thus resulting in a beneficial effect.

It can be seen from the abovementioned research studies that closed-cell aluminum foam material has rarely been used in the field in order to provide improved impact resistance to bridge structures. Based on the engineering applications of stainless-steel reinforced concrete bridge piers in the Hong Kong-Zhuhai-Macao Bridge, this study selected closed-cell aluminum foam material as the protection device of the bridge piers. This study then discussed and analyzed the entire impact process of concrete bridge piers containing stainless-steel bars as replacements for ordinary steel bars under the conditions of anticollision material. The results obtained in this study potentially provide valuable references for future reliability analyses of the closed-cell aluminum foam buffering materials used in pier protection devices.

\section{Test Overview}

2.1. Specimen Design. In order to study the impact performances of closed-cell aluminum foam material on the ordinary reinforced concrete pier replaced by stainless-steel bars of equal strength under horizontal impact loads, a scale model of four circular section piers was designed with the proportion of $1: 5$ to be used as this study's specimen, as shown in Figure 1. The height and diameter of the specimen were $2,200 \mathrm{~mm}$ and $340 \mathrm{~mm}$, respectively. There were ten longitudinal bars in the 


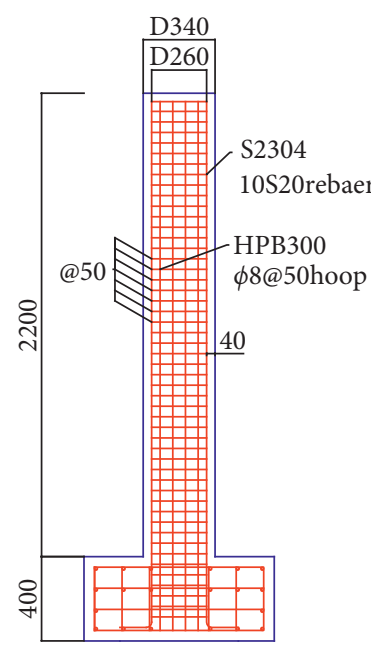

(a)

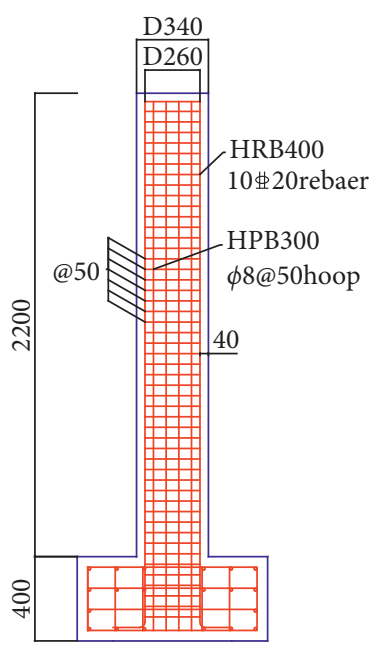

(b)
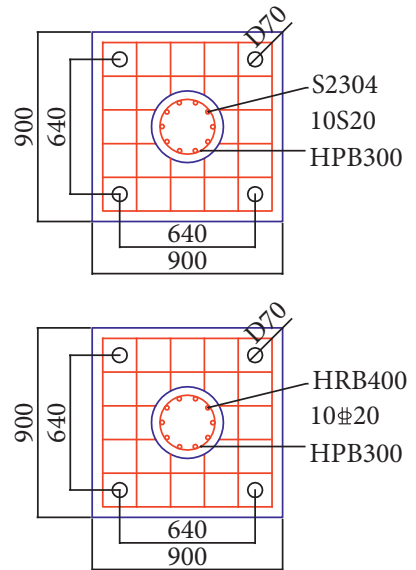

(c)

FIgURE 1: Schematic diagram of the specimen (dimension unit: $\mathrm{mm}$ ).

specimen, which were symmetrically arranged in the direction of a circular section. Among those, the stainless-steel bars were S2304 two-phase stainless-steel bars produced by the UGITECH Co. (France) and the ordinary steel bars were HRB400 steel bars. The stirrup was a Grade I ordinary steel bar HPB300 with a diameter of $8 \mathrm{~mm}$, which was welded into the construction. The concrete strength was C40. During this study's testing process, a closed-cell aluminum foam material with a density of $0.4 \mathrm{~g} / \mathrm{cm}^{3}$, thicknesses of $50 \mathrm{~mm}$ and $100 \mathrm{~mm}$, length of $210 \mathrm{~mm}$, and width of $100 \mathrm{~mm}$ (Figure 2) was applied as the protection material of the reinforced concrete piers. The mechanical performance indexes of the protective material were measured in this study's laboratory facilities. The parameters of closed-cell aluminum foam are shown in Table 1 .

The stress-strain curves were obtained by the uniaxial compression test on the selected closed-cell aluminum foam material. Figure 3 shows the stress-strain curves obtained by the $50 \mathrm{~mm}$ and $100 \mathrm{~mm}$ closed-cell aluminum foam uniaxial compression tests. From the stress-strain curves, it can be seen that the assessments were completed using the deformations [30]:

$$
W=\int_{0}^{\varepsilon_{m}} \sigma \mathrm{d} \varepsilon
$$

where $w$ is the deformation work of closed-cell aluminum foam absorbed; $\sigma$ is the flow stress of closed-cell aluminum foam; and $\varepsilon_{m}$ is the flow strain of closed-cell aluminum foam.

In accordance with the results shown in Figures 3(a) and 3 (b), the compression stress-strain curves of the closed-cell aluminum foam showed three stages as follows: linear elastic deformation stage; plastic platform stage; and densification stage. After the aluminum foam entered the yield stage, a long yield platform had formed. It was found that the longer this platform was, the higher its energy consumption capacity would be [17].

The yield strength, ultimate strength, and bearing capacity of the stainless-steel bars and ordinary steel bars were obtained through the completion of tensile tests for the steel

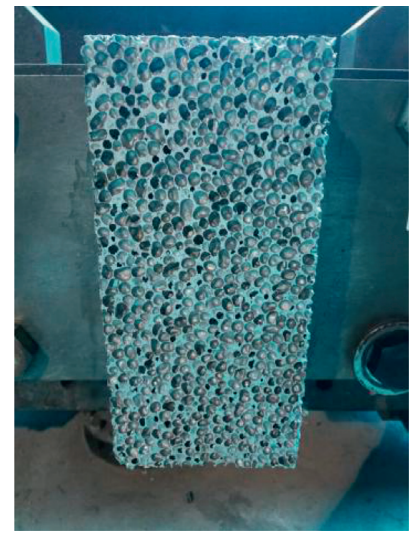

Figure 2: Closed-cell aluminum foam material.

bars. The yield strengths of the stainless-steel bars were $0.2 \%$ of the residual strain. Twelve cubes measuring $150 \mathrm{~mm} \times 150 \mathrm{~mm} \times 150 \mathrm{~mm}$ were constructed in order to perform compressive strength tests of the concrete. In addition, the axial compressive strength of the concrete was measured. The specimen design is detailed in Table 2, the steel bar material performance in Table 3, and the mechanical properties of the concrete in Table 4 .

2.2. Test Device and Design. This study's tests were carried out on a multifunctional ultrahigh heavy drop hammer test machine. The test device is shown in Figure 4. The multifunctional ultrahigh heavy drop hammer test machine consisted of three parts: vertical drop hammer, trolley, and wire rope. The weight of the vertical drop hammer was $166 \mathrm{~kg}$, and the weight of the trolley was $1,200 \mathrm{~kg}$. These weights could be changed by increasing the counterweights. The kinetic energy of the trolley was provided by changing the vertical drop weight, as shown in Figure 5. Among them, the maximum height to which the drop hammer could be lifted was $18 \mathrm{~m}$, and the change range of the drop hammer 
TABLE 1: Parameters of the closed-cell aluminum foam material.

\begin{tabular}{lcccccc}
\hline $\begin{array}{l}\text { Material } \\
\text { no. }\end{array}$ & $\begin{array}{c}\text { Volume density } \\
\left(\mathrm{g} / \mathrm{cm}^{3}\right)\end{array}$ & Thickness $(\mathrm{mm})$ & Porosity $(\%)$ & $\begin{array}{c}\text { Compressive strength } \\
\left(\mathrm{N} / \mathrm{mm}^{2}\right)\end{array}$ & $\begin{array}{c}\text { Tensile strength } \\
\left(\mathrm{N} / \mathrm{mm}^{2}\right)\end{array}$ & $\begin{array}{c}\text { Deformation } \\
\text { work }(\mathrm{J})\end{array}$ \\
\hline A1 & 0.4 & 50 & 85 & 5.7 & 3.0 & 3183 \\
A2 & 0.4 & 100 & 85 & 6.0 & 3.0 & 4880 \\
\hline
\end{tabular}

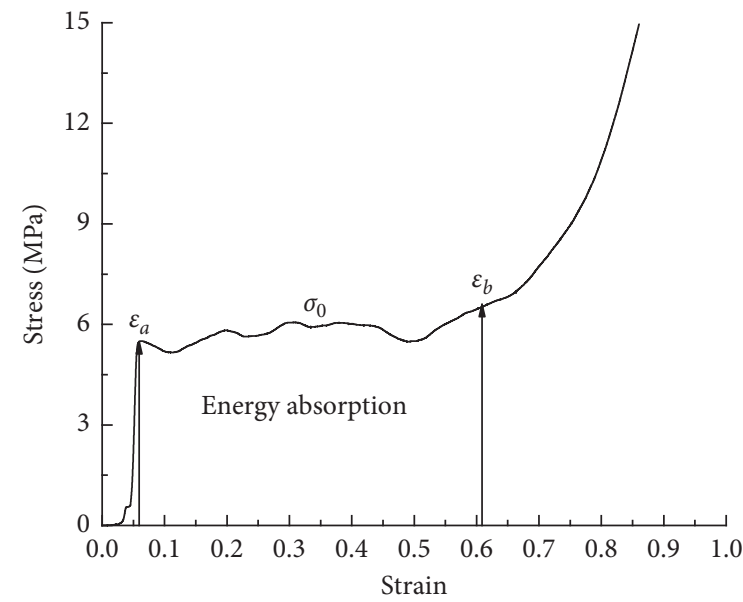

_ Volume density $0.4\left(\mathrm{~g} / \mathrm{cm}^{3}\right)$ Size $100 \mathrm{~m} * 100 \mathrm{~mm} * 50 \mathrm{~mm}$

(a)

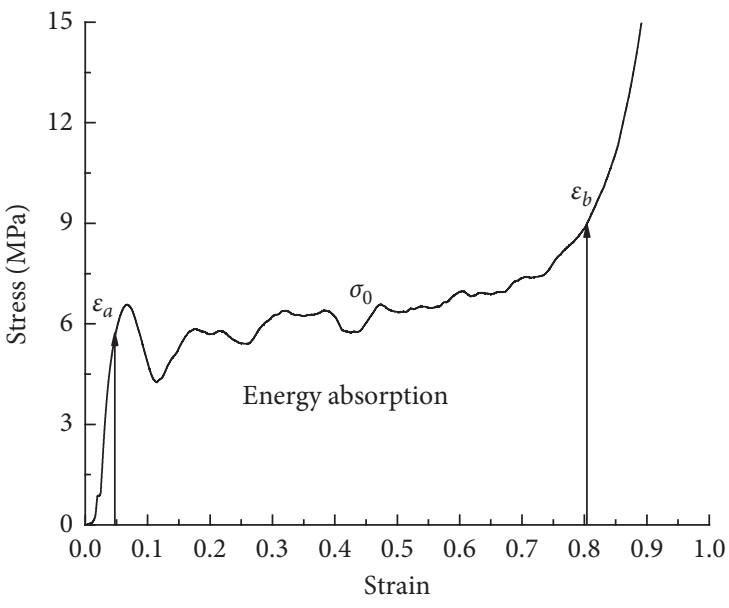

- Volume density $0.4\left(\mathrm{~g} / \mathrm{cm}^{3}\right)$ Size $100 \mathrm{~m} * 100 \mathrm{~mm} * 100 \mathrm{~mm}$

(b)

Figure 3: Stress-strain curves of the uniaxial compression tests of the closed-cell aluminum foam.

TABle 2: Design of the test specimen.

\begin{tabular}{|c|c|c|c|c|c|}
\hline Group & Specimen no. & Longitudinal reinforcement $(\mathrm{mm})$ & Stirrup $(\mathrm{mm})$ & Concrete strength grade & $\begin{array}{c}\text { Aluminum foam no. } \\
\text { used for specimen }\end{array}$ \\
\hline \multirow{2}{*}{-} & S1-16 & $10 S 16$ & Ф8@50 & $\mathrm{C} 40$ & $\mathrm{~A} 1$ \\
\hline & $\mathrm{Z} 2-16$ & $10 \Phi 16$ & Ф8@50 & $\mathrm{C} 40$ & A1 \\
\hline \multirow{2}{*}{$=$} & S1-20 & $10 S 20$ & Ф8@50 & $\mathrm{C} 40$ & $\mathrm{~A} 2$ \\
\hline & $\mathrm{Z} 2-20$ & $10 \Phi 20$ & Ф8@50 & $\mathrm{C} 40$ & $\mathrm{~A} 2$ \\
\hline
\end{tabular}

Note. In the table, S represents the stainless steel (S2304).

TABle 3: Performance of the steel bar material.

Longitudinal reinforcement Steel diameter $(\mathrm{mm})$ Yield strength $\left(\mathrm{N} / \mathrm{mm}^{2}\right)$ Ultimate strength $\left(\mathrm{N} / \mathrm{mm}^{2}\right)$ Elasticity modulus $\left(\mathrm{N} / \mathrm{mm}^{2}\right)$

\begin{tabular}{lllll}
\hline \multirow{2}{*}{ HPB400 } & 16 & 420 & 540 & $2.00 \times 10^{5}$ \\
& 20 & 440 & 580 & 734 \\
\multirow{2}{*}{ S2304 } & 16 & 670 & 858 & $1.93 \times 10^{5}$ \\
& 20 & 720 & & 858 \\
\hline
\end{tabular}

TABLE 4: Mechanical properties of the concrete.

\begin{tabular}{lcc}
\hline Concrete strength grade & Concrete strength $\left(\mathrm{N} / \mathrm{mm}^{2}\right)$ & Modulus of elasticity $\left(\mathrm{N} / \mathrm{mm}^{2}\right)$ \\
\hline C40 & 44.83 & $3.28 \times 10^{4}$ \\
\hline
\end{tabular}

weight was between $166 \mathrm{~kg}$ and 1,500 kg. During this study's tests, the counterweight of the drop hammer was $196 \mathrm{~kg}$, and the weight of the trolley was $1,200 \mathrm{~kg}$.

In this study, prior to the simulated collision, the base of the column was connected with the foundation using four screws, which were approximately equivalent to a rigid joint. Then, $250 \mathrm{kN}$ of axial pressure was applied on the top of the column in order to limit the horizontal displacement of the column, as shown in Figure 6. After the sample was established in its place, a closed-cell foam aluminum buffer material was fixed on the rigid bow of the impacting boat model (Figure 7), and the drop hammer was systematically lifted to heights of $2 \mathrm{~m}, 4 \mathrm{~m}, 6 \mathrm{~m}, 8 \mathrm{~m}, 10 \mathrm{~m}$, and $12 \mathrm{~m}$, respectively. In this way, cumulative impact tests were 


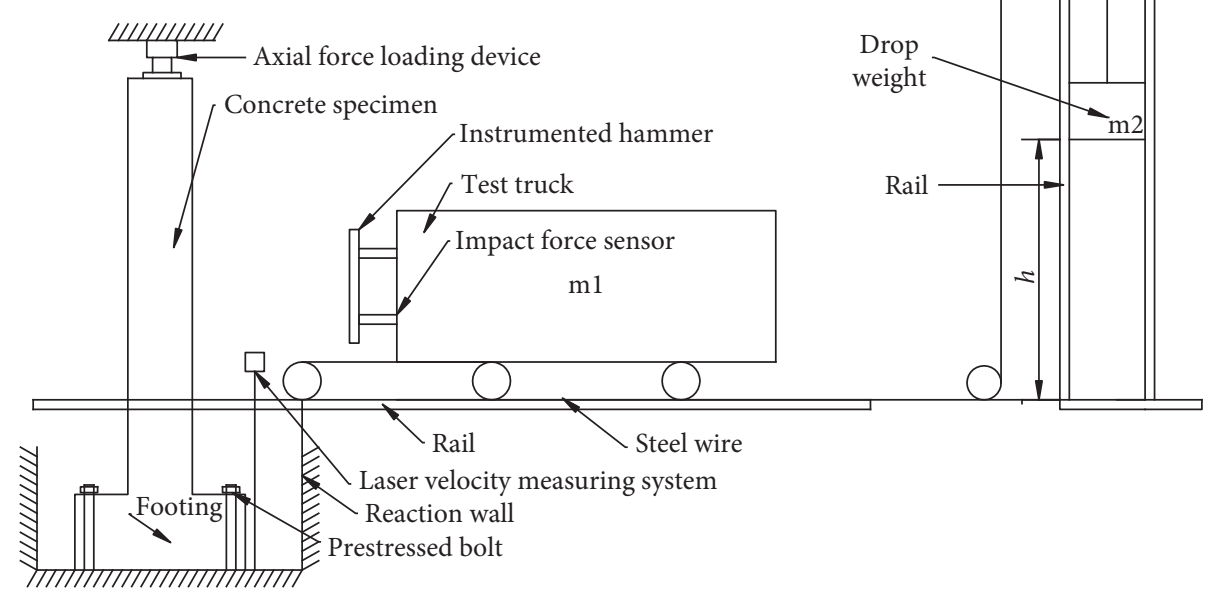

FIgURE 4: Multifunctional ultrahigh heavy drop hammer impact testing machine system.

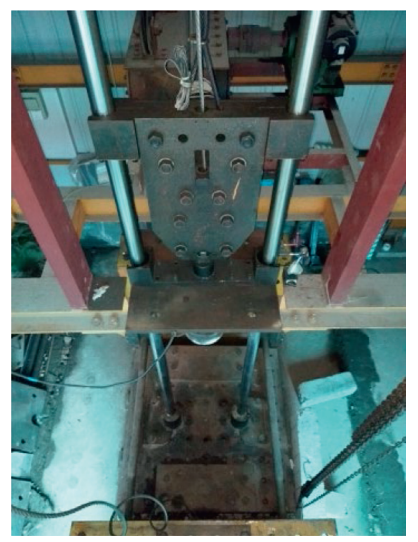

FIGURE 5: Vertical drop hammer.

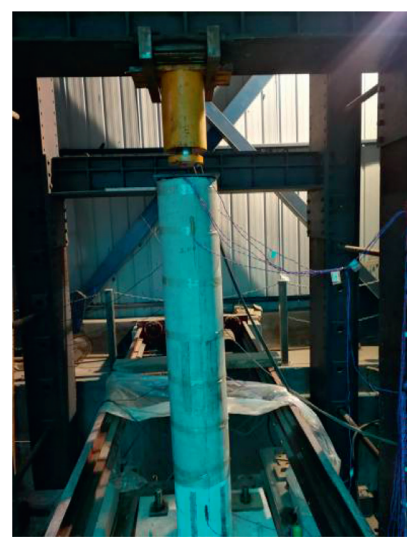

Figure 6: Impacted specimen and constraints.

completed on the reinforced concrete pier model. During the aforementioned process, it was ensured that the steel wire rope connecting the drop hammer was in a tensile state,

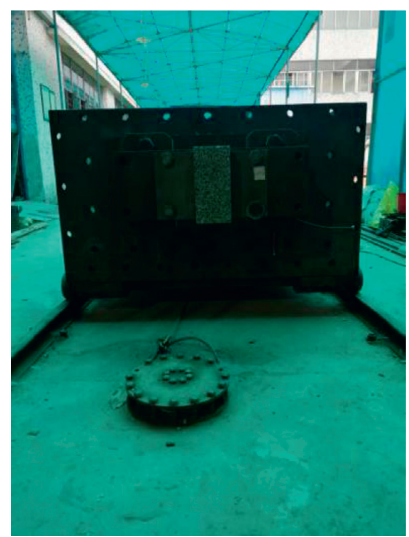

Figure 7: Horizontal traction impact test.

and then the drop hammer was released to pull the car against the specimen. The heights of the drop hammer were changed in order to cause the car to simulate different impact speeds.

According to the experimental design, each pier is impacted six times, and the impact scheme is as shown in Table 5.

2.3. Data Collection. The testing results of the impact force, specimen displacement, strain of the steel bar, and crack development of the specimen, along with the damages to the concrete, were recorded. Among the aforementioned data, the impact force was measured by a pressure sensor at the head of the car, and the dynamic strain of the steel bar was measured using a strain gauge. Then, in accordance with the stress characteristics of the specimen, a total of eight strain gauges were arranged on the steel bar. The gauge distribution is shown in Figure 8. In addition, four displacement meters 
TABLE 5: Impact scheme.

\begin{tabular}{|c|c|c|c|c|c|}
\hline $\begin{array}{l}\text { Specimen } \\
\text { no. }\end{array}$ & $\begin{array}{l}\text { Impact } \\
\text { times }\end{array}$ & $\begin{array}{l}\text { Height of the drop } \\
\text { hammer }(\mathrm{m})\end{array}$ & $\begin{array}{l}\text { Average impact velocity } \\
\qquad(\mathrm{m} / \mathrm{s})\end{array}$ & $\begin{array}{c}\text { Accumulated energy } \\
(\mathrm{J})\end{array}$ & $\begin{array}{l}\text { Stress stage of closed-cell } \\
\text { aluminum foam }\end{array}$ \\
\hline & 1 & 2 & 0.72 & 311.04 & \\
\hline S1-16 & 2 & 4 & 1.10 & 1037.04 & Yield stage \\
\hline $\mathrm{Z} 2-20$ & 3 & 6 & 1.42 & 2246.88 & \\
\hline S1-20 & 4 & 8 & 1.67 & 3920.22 & \\
\hline \multirow[t]{2}{*}{$\mathrm{Z} 2-25$} & 5 & 10 & 1.84 & 5951.58 & Densification stage \\
\hline & 6 & 12 & 2.08 & 8547.42 & \\
\hline
\end{tabular}

were arranged at the locations of $100 \mathrm{~mm}, 800 \mathrm{~mm}$, $1,500 \mathrm{~mm}$, and $2,100 \mathrm{~mm}$ from the top to the bottom on the back of specimen for the purpose of collecting the lateral displacement data of the bridge column (Figure 9). An HCU81 concrete ultrasonic detector was adopted to detect the main failure area of the specimen.

\section{Results of the Experimental Tests and Analyses}

In the present study, under different impact energies, the dynamic response data of the ordinary reinforced concrete bridge piers and the stainless-steel reinforced concrete bridge piers were obtained. This data mainly included the impact force time history curves, displacement time history curves, reinforcement strain time history curves, damage situation in some areas of the specimen, and the crack development and failure modes. In order to more effectively analyze the dynamic responses of the two groups of specimens, the zero point of time was defined as when the car reached the laser speed measurement system at the end of the track, i.e., when the acquisition system was triggered.

3.1. Impact Response Analysis. In the present study, under the condition of the application of closed-cell aluminum foam, the impact resistance abilities before and after equal section replacements with stainless-steel bars were obviously different. Figure 10 shows the impact force time history curves of specimens S1-16, Z2-16, S1-20, and Z2-20 when the drop hammer was lifted to $4 \mathrm{~m}$ and $10 \mathrm{~m}$, respectively. It can be seen in the figure that specimens S1-16 (S representing stainlesssteel) and Z2-16 had $50 \mathrm{~mm}$ closed-cell aluminum foam applications. Also, specimens S1-20 (S representing stainlesssteel) and Z2-20 had $100 \mathrm{~mm}$ closed-cell aluminum foam applications.

It can be seen in Figure 10 that the impact force time history curve of the stainless-steel reinforced concrete bridge pier and the ordinary reinforced concrete bridge pier were relatively consistent for the equal cross-section replacement of the pier with stainless-steel bars under the protection of the closed-cell aluminum foam. The process could be roughly divided into three stages: peak stage, platform value stage, and unloading stage. First, a peak had appeared in the curve; then, the curve decreased and oscillated for a period of time near a certain value, and then unloaded slowly until the impact force time history curve changes had become

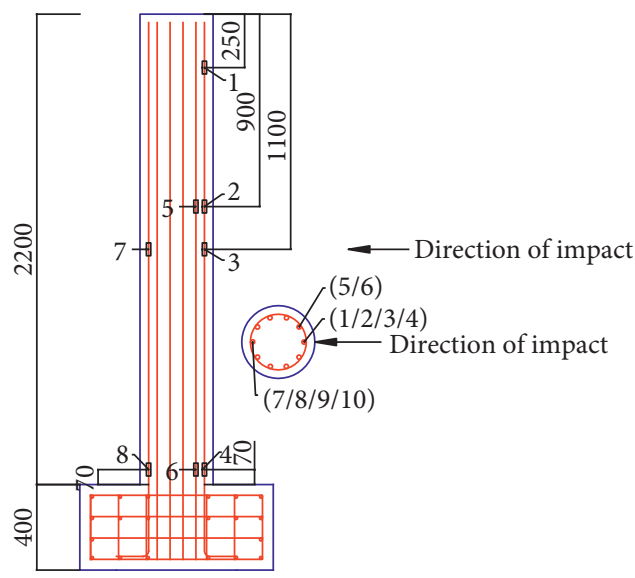

FIgURE 8: Strain measurement points of the steel bars (unit: $\mathrm{mm}$ ).

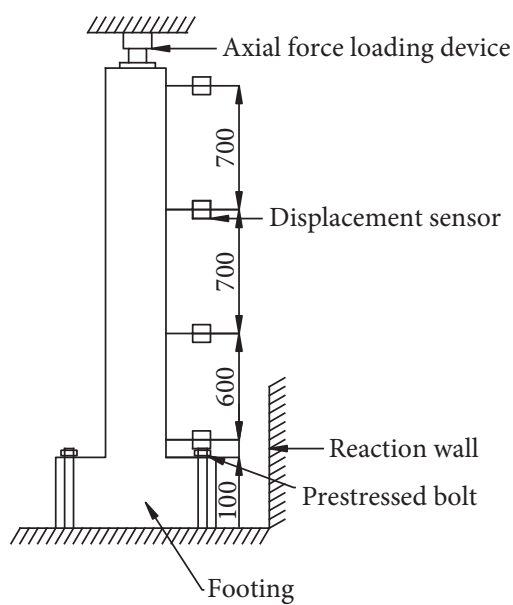

FIgURE 9: Displacement measurement points (unit: $\mathrm{mm}$ ).

relatively smooth. During the entire impact process, the impact force reached the peak value rapidly (within $0.05 \mathrm{~s}$ ), and the duration of the peak value was very short. Therefore, in order to further understand the protective performances of the three stages of the closed-cell aluminum foam on the equal cross-section piers, the peak impact test results of the two groups of piers were compared, as shown in Table 6.

As shown in Table 6, the impact forces of specimens Z2-16/ Z2-20 and S1-16/S1-20 gradually draw near to each other with the loss of the buffering effect of the aluminum foam under the same impact condition before and after the equal-strength replacement of stainless-steel reinforcement. However, overall, the impact force of Z2-16 and Z2-20 is smaller than that of S1- 

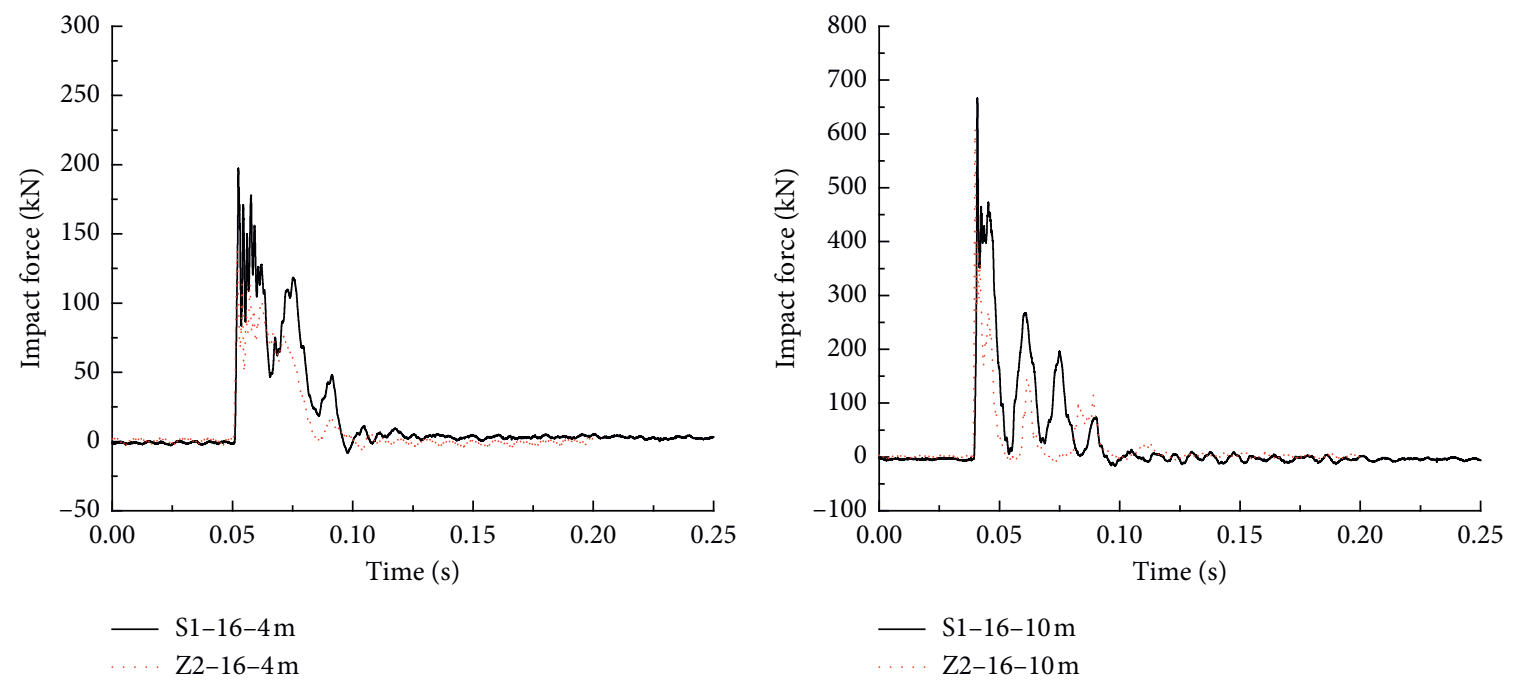

(a)

(b)

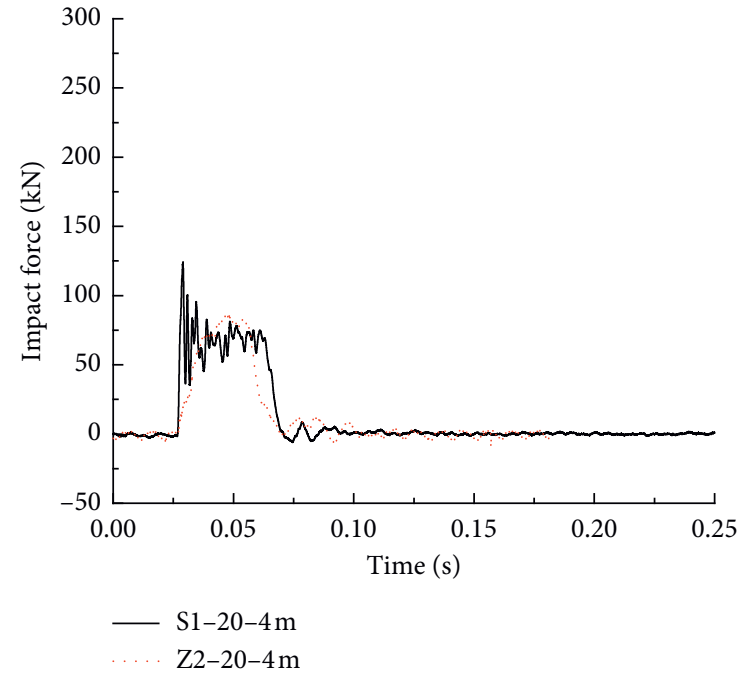

(c)

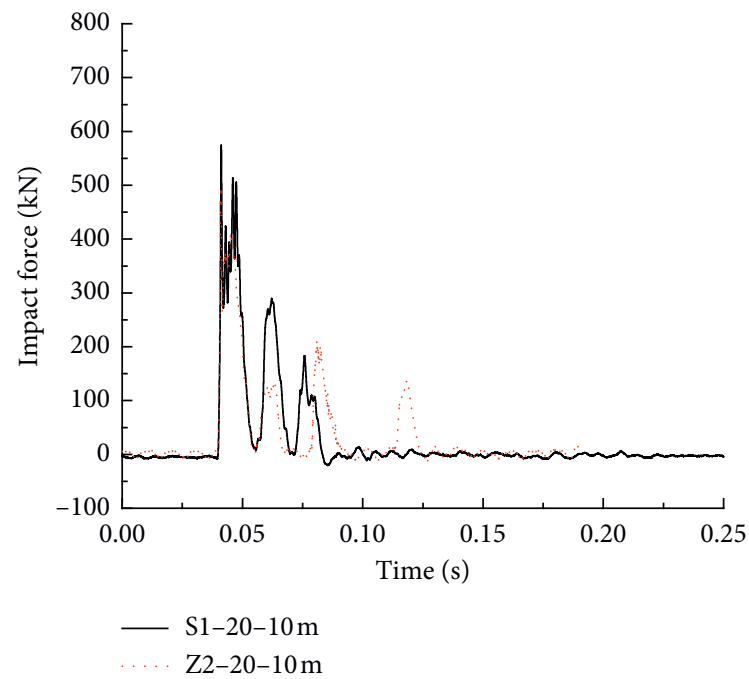

(d)

FIGURE 10: Time history curve of the impact forces when the drop hammer was lifted to $4 \mathrm{~m}$ and $10 \mathrm{~m}$, respectively. In the figure, diameter 16 is $50 \mathrm{~mm}$ closed-cell aluminum foam, and diameter 20 is $100 \mathrm{~mm}$ closed-cell aluminum foam.

TABLE 6: Impact force test results and comparison.

\begin{tabular}{|c|c|c|c|c|c|c|c|}
\hline \multirow{3}{*}{$\begin{array}{l}\text { Height of the drop } \\
\text { hammer }(\mathrm{m})\end{array}$} & \multirow{3}{*}{$\begin{array}{l}\text { Average impact } \\
\text { velocity }(\mathrm{m} / \mathrm{s})\end{array}$} & \multicolumn{3}{|c|}{$1^{\text {st }}$ group } & \multicolumn{3}{|c|}{$2^{\text {nd }}$ group } \\
\hline & & \multicolumn{2}{|c|}{$\begin{array}{l}\text { Peak impact } \\
\text { force }(\mathrm{kN})\end{array}$} & \multirow[t]{2}{*}{ Relative ratio (\%) } & \multicolumn{2}{|c|}{$\begin{array}{l}\text { Peak impact } \\
\text { force }(\mathrm{kN})\end{array}$} & \multirow[t]{2}{*}{ Relative ratio (\%) } \\
\hline & & S1-16 & Z2-16 & & S1-20 & $\mathrm{Z} 2-20$ & \\
\hline 2 & 0.72 & 111.57 & 68.95 & 38.2 & 89.3 & 61.9 & 30.68 \\
\hline 4 & 1.10 & 200.49 & 138.41 & 30.96 & 124.61 & 87.95 & 29.42 \\
\hline 6 & 1.42 & 313.66 & 202.72 & 35.37 & 153.47 & 114.47 & 25.41 \\
\hline 8 & 1.67 & 478.85 & 360.65 & 24.68 & 349.4 & 292.82 & 16.19 \\
\hline 10 & 1.84 & 672.11 & 618.28 & 8.01 & 578.77 & 498.52 & 13.87 \\
\hline 12 & 2.08 & 830.39 & 756.08 & 8.95 & 781.72 & 737.35 & 5.68 \\
\hline
\end{tabular}

16 and S2-20, which is mainly due to the higher strength and toughness of stainless steel, which improves the overall stiffness of the specimen; this shows that the impact force is related to the overall stiffness of the specimen. By comparing the peak impact force of two groups, the impact speed is fitted with the impact force, as shown by the peak impact force in the first and second groups in Figure 11. Finally, Figure 12 shows specimen S1-16 following the cumulative impacts.

It can be seen in Figure 11 that the change rule of the impact force of the two groups of specimens was approximately the same 


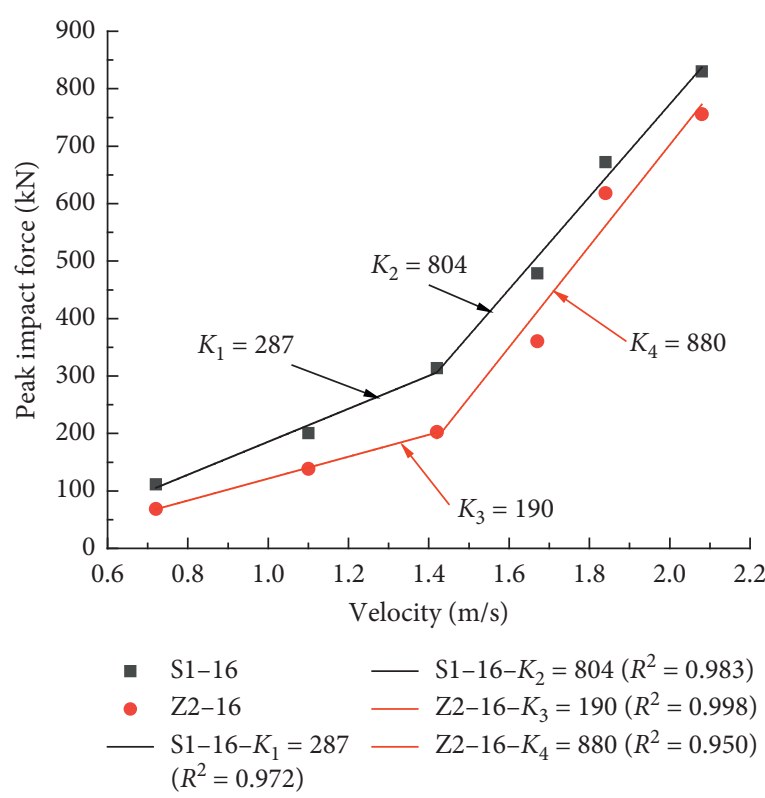

(a)

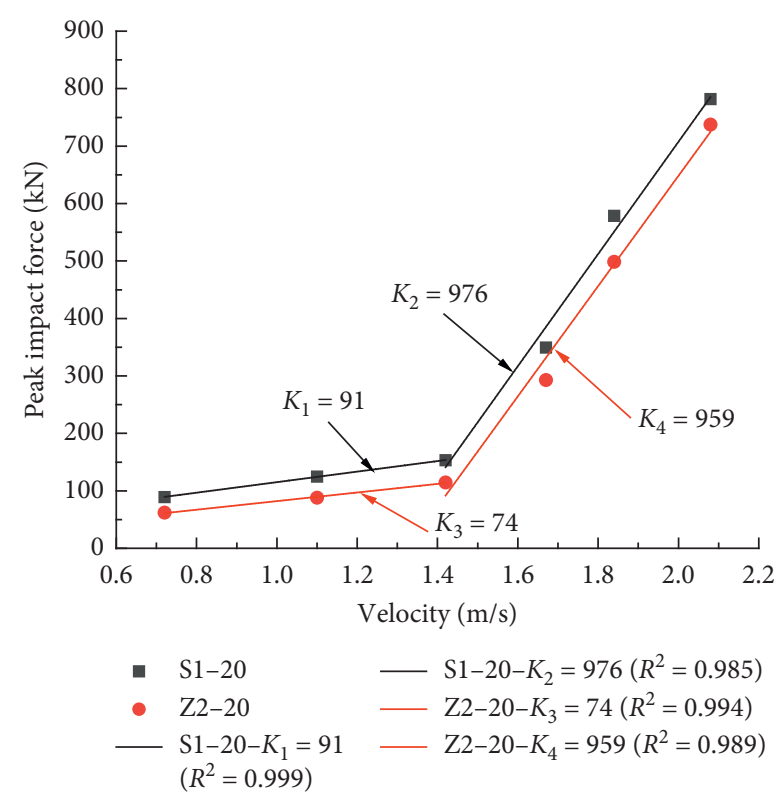

(b)

FIGURE 11: The peak value of the impact force of the first and second groups.

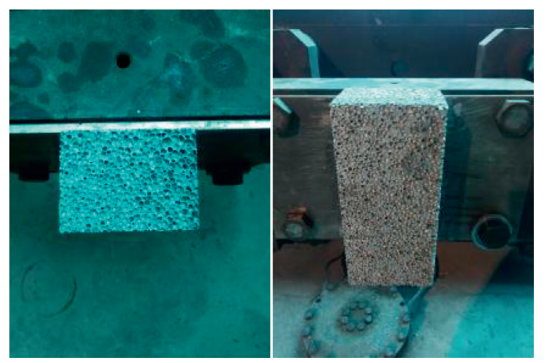

(a)

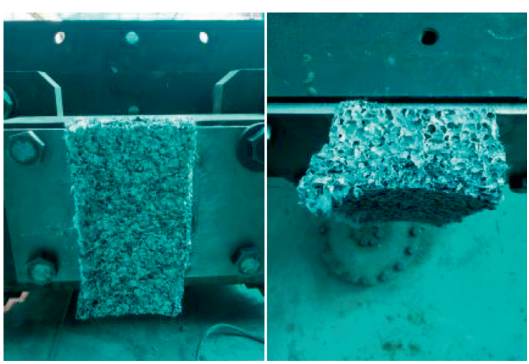

(b)

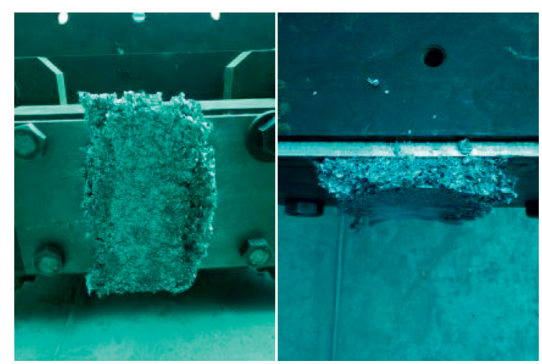

(c)

FIGURE 12: Images of specimen S1-16 closed-cell aluminum foam following impacts. In the figure, the number after specimen S1-16 denotes the lifting height of the drop hammer, unit: m. (a) S1-16-0, (b) S1-16-4, and (c) S1-16-12.

and had increased with the increases in the impact speed. When the impact speed was less than $1.42 \mathrm{~m} / \mathrm{s}$, the increases in the impact forces of all the specimens had been relatively slow. This was determined to be mainly due to the fact that the closed-cell aluminum foam was in either an elastic stage or yield stage at this point, and the closed-cell aluminum foam exhibited good energy consumption performance. However, when the impact speed was greater than $1.42 \mathrm{~m} / \mathrm{s}$, the impact forces of all the specimens had increased sharply as a result of the accumulation of impact energy, and the closed-cell aluminum foam had transitioned from a yield platform stage to a densification stage. Therefore, the impact energy absorption capacity of the closedcell aluminum foam had decreased dramatically. This property is consistent with the stress-strain curve obtained from the uniaxial compression test of the closed-cell aluminum foam, as shown in Figure 3.

3.2. Displacement Time History Curves. Figure 13 shows the displacement time history curves of the tops of the specimens with longitudinal steel bar diameters of $16 \mathrm{~mm}$ $(50 \mathrm{~mm}$ thick closed-cell aluminum foam) and $20 \mathrm{~mm}$ ( $100 \mathrm{~mm}$ thick closed-cell aluminum foam) under the actions of lifting the drop hammer to $4 \mathrm{~m}$ and $10 \mathrm{~m}$, respectively.

Figures 13(a) and 13(c) illustrate that when the drop hammer was lifted to $4 \mathrm{~m}$, the maximum displacements of the $16 \mathrm{~mm}$ diameter specimens (Z2-16-4 m and S1-16-4 m) were $22.9 \mathrm{~mm}$ and $17.79 \mathrm{~mm}$, respectively. The maximum displacements of the $20 \mathrm{~mm}$ diameter specimens (Z2-20-4 $\mathrm{m}$ and S1-20-4 $\mathrm{m}$ ) were $16.74 \mathrm{~mm}$ and $13.15 \mathrm{~mm}$, respectively. In addition, it can be seen in Figures 13(b) and 13(d) that when the drop hammer was lifted to $10 \mathrm{~m}$, the maximum displacements of the $16 \mathrm{~mm}$ diameter specimens (Z2-16-10 $\mathrm{m}$ and $\mathrm{S} 1-16-10 \mathrm{~m}$ ) were $93.92 \mathrm{~mm}$ and $54.33 \mathrm{~mm}$, respectively. The maximum displacements of the $20 \mathrm{~mm}$ diameter specimens (Z2-20-10 $\mathrm{m}$ and S1-20-10 $\mathrm{m}$ ) at a drop hammer height of $10 \mathrm{~m}$ were $70.69 \mathrm{~mm}$ and $46.49 \mathrm{~mm}$, respectively. Therefore, it was ascertained from the abovementioned results that, under the conditions of using closed-cell 


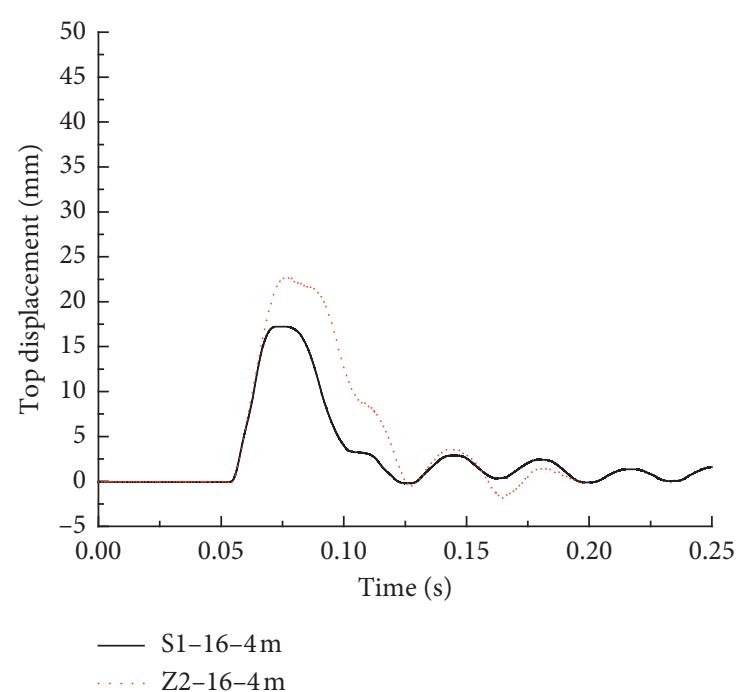

(a)

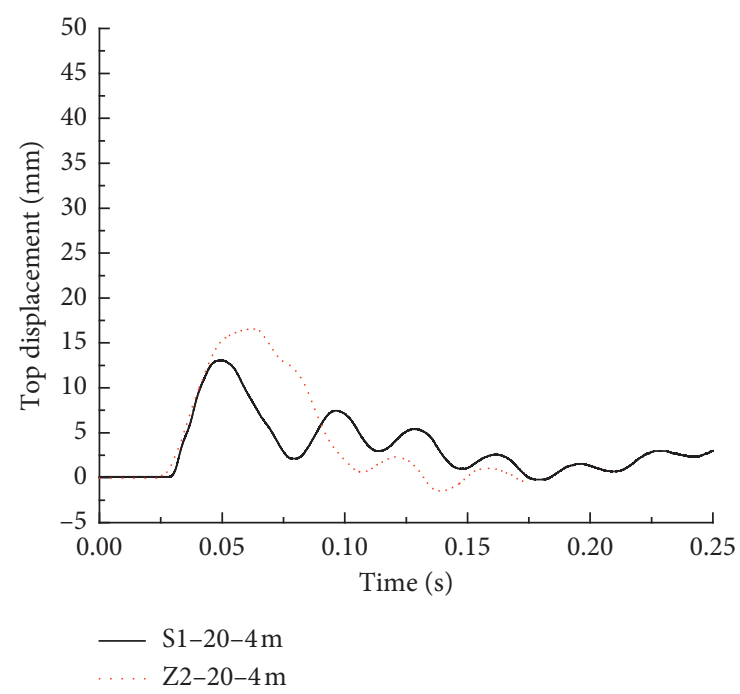

(c)

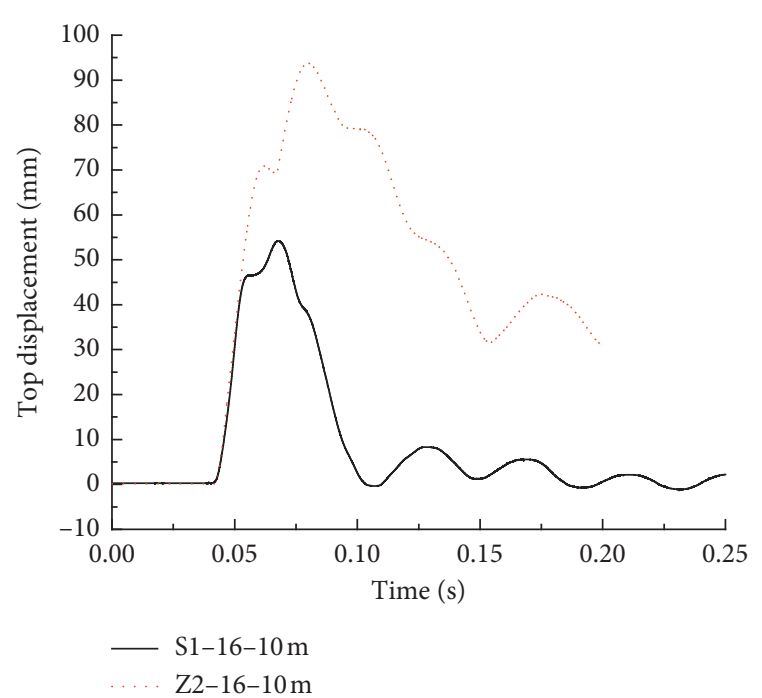

(b)

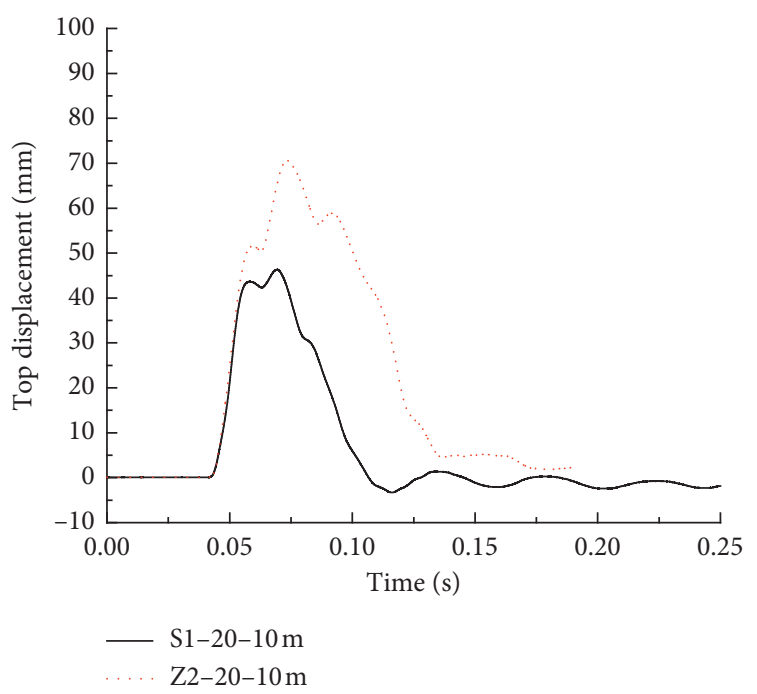

(d)

Figure 13: Time history curve of the top displacements of the specimens with the drop hammer lifted to $4 \mathrm{~m}$ and $10 \mathrm{~m}$, respectively. In the figure, diameter 16 has a $50 \mathrm{~mm}$ closed-cell aluminum foam application and diameter 20 has a $100 \mathrm{~mm}$ closed-cell aluminum foam application.

foam aluminum as buffer layers, for the stainless-steel bar replacements in the concrete piers with equal cross-sections, the impact displacements of the stainless-steel reinforced concrete piers were smaller than those of the ordinary reinforced concrete piers. It was observed that the displacement gaps increased with increases in the impacting energy. In the present study, in order to further analyze the displacement responses of the piers under impacting conditions, the peak displacement test data of the two groups of pier components were compared and analyzed. The results are detailed in Table 7.

It can be seen from Table 7 that when the impact speed was low (for example, less than $1.42 \mathrm{~m} / \mathrm{s}$ ), the relative displacement ratios of the two groups of piers were relatively stable at approximately $22 \%$. During the process, the closedcell aluminum foam was in either an elastic stage or a yield stage. It was found that the closed-cell aluminum foam could potentially play a key role in the energy consumption performance. However, when the impact speed was larger (for example, more than $1.67 \mathrm{~m} / \mathrm{s}$ ), the relative displacement ratios of the measuring points displayed increasing trends and had increased from a stable value of $22 \%$ to approximately $42 \%$, and from a stable value of $22 \%$ to approximately $34 \%$, for the two groups, respectively. At that stage, the closed-cell aluminum foam had entered a densification stage and its energy consumption performance decreased sharply, which intensified the dynamic responses of the impacted structure to a certain extent. The densification effects on the ordinary reinforced concrete members were found to be greater than those of the stainless-steel reinforced concrete members, and the influence gap increased with the increases in the densification degree. Figure 14 shows the change rule of the peak displacements of the measuring points. 
TABLE 7: Test results and comparison of the top displacements.

\begin{tabular}{|c|c|c|c|c|c|c|c|}
\hline \multirow{3}{*}{$\begin{array}{l}\text { Height of the } \\
\text { drop hammer }(\mathrm{m})\end{array}$} & \multirow{3}{*}{$\begin{array}{l}\text { Average impact } \\
\text { velocity }(\mathrm{m} / \mathrm{s})\end{array}$} & \multicolumn{3}{|c|}{$1^{\text {st }}$ group } & \multicolumn{3}{|c|}{$2^{\text {nd }}$ group } \\
\hline & & \multicolumn{2}{|c|}{$\begin{array}{l}\text { Displacement peak } \\
\text { values }(\mathrm{mm})\end{array}$} & \multirow{2}{*}{$\begin{array}{l}\text { Relative } \\
\text { ratio (\%) }\end{array}$} & \multicolumn{2}{|c|}{$\begin{array}{l}\text { Displacement peak } \\
\text { values }(\mathrm{mm})\end{array}$} & \multirow{2}{*}{$\begin{array}{l}\text { Relative } \\
\text { ratio (\%) }\end{array}$} \\
\hline & & S1-16 & Z2-16 & & $\mathrm{S} 1-20$ & $\mathrm{Z} 2-20$ & \\
\hline 2 & 0.72 & 10.19 & 13.02 & 21.74 & 10.98 & 13.94 & 21.23 \\
\hline 4 & 1.10 & 17.79 & 22.9 & 22.31 & 13.15 & 16.74 & 21.45 \\
\hline 6 & 1.42 & 32.11 & 41.78 & 23.15 & 20.75 & 26.99 & 23.12 \\
\hline 8 & 1.67 & 41.76 & 66.91 & 37.59 & 32.1 & 48.13 & 33.31 \\
\hline 10 & 1.84 & 54.33 & 93.92 & 42.15 & 46.49 & 70.69 & 34.23 \\
\hline 12 & 2.08 & 70.13 & 121.31 & 42.19 & 57.55 & 87.34 & 34.11 \\
\hline
\end{tabular}

It can be seen in Figure 14 that the impact displacements at the measuring points of the ordinary reinforced concrete bridge pier were larger than those at the same measuring points of the stainless-steel reinforced concrete bridge pier. The change rule of the impact displacements at the measuring points of the two groups of experimental members was approximately the same, and had increased with the increases in the impacting speed. When the impact speed was less than $1.42 \mathrm{~m} / \mathrm{s}$, the increases in the impact displacements at the tops of the structures were relatively slow. This was mainly due to the fact that the closed-cell aluminum foam at that stage was in an elastic or yield stage and had the ability to effectively absorb the impact energy. However, when the impact speed was greater than $1.42 \mathrm{~m} / \mathrm{s}$, the top displacements had rapidly increased. This was determined to mainly be due to the fact that the closed-cell aluminum foam had reached a densification stage with the increases in the impact energy, resulting in a gradual loss of buffering ability. The overall rigidity of the closed-cell aluminum foam increased after compression densification, resulting in increases of the impact responses of the structures and the occurrence of more displacements. Therefore, the densification stage was found to be characterized by increases in the dynamic responses of the examined bridge piers. Subsequently, it was indicated that it is necessary to replace closed-cell aluminum foam material in a time manner when it is used as the buffer material for bridge piers.

3.3. Strain Time History Curves. Figure 15 shows the peak strain curve of the No. 4 steel bars located in the lower part of the front of the impact point when the drop hammer was lifted to $4 \mathrm{~m}$ and $10 \mathrm{~m}$, respectively.

It can be seen from Figure 14 that the strain time history curve and peak change trend of the equal-strength replacement specimen are basically the same, under the same impact energy. Additionally, the strain variation of ordinary reinforced concrete specimens and stainless-steel specimens is larger. Next, from the stress-strain formula $(\sigma=\varepsilon \times E)$, the stress value of the reinforcement is obtained. Finally, the stress values of the different yield strengths of reinforcement are compared (Table 4), and the peak strain and stress of two groups of No. 4 reinforcement shown in Table 8 are obtained.
According to the strain values of the reinforcement detailed in Table 8, the peak strain of the reinforcement of each specimen also increased with the increases in impact height. Under the conditions of the closed-cell aluminum foam protection, before and after the replacements with stainless steel of equal cross-sections, the peak strain values of the steel bars in the S1-16 and S1-20 specimens were found to be smaller than those of the Z2-16 and Z2-20 specimens. This was determined to be mainly due to the stainless-steel bars having higher strength and plasticity, which had effectively improved the impact resistance and reduced the ductility of the piers. In addition, the densification of the closed-cell aluminum foam had certain impacts on the strain of the steel bars at the first group of measuring points. However, it had no obvious impacts on the steel bars at the second group of measurement points. This was mainly caused by the different impact resistance abilities and impact failure modes of the components. The stress values of the reinforcements, and the relationships between the stress values of the reinforcements and impact velocities were determined in accordance with the peak strain values of the two groups of No. 4 reinforcements (Table 7). The results are displayed in Figure 16.

Figure 16 shows that the steel bars of specimens S1-16 and S1-20 had not yielded before and after the replacements of stainless steel of equal cross-sections. These results indicated that the stainless-steel concrete specimens had displayed the ability to resist greater impact forces under the same impact conditions. Subsequently, the members were not damaged. It was observed that under the same impact conditions, the reinforced concrete piers had been better protected by increasing the thickness of the aluminum foam. This had been demonstrated by the fact that the steel bar of the Z2-20 specimen had not reached the yield stage.

3.4. Inspection of the Concrete Damages. Table 9 shows the changes in the acoustic parameters of the stainless-steel reinforced concrete and ordinary reinforced concrete following the damages recorded using a concrete ultrasonic loss tester. In this study's experiments, it was observed that following the concrete specimens suffering damages, the propagation of the ultrasonic waves had changed. Due to the fact that the waves needed to propagate directly through or around the cracks, the propagation times of the ultrasonic 

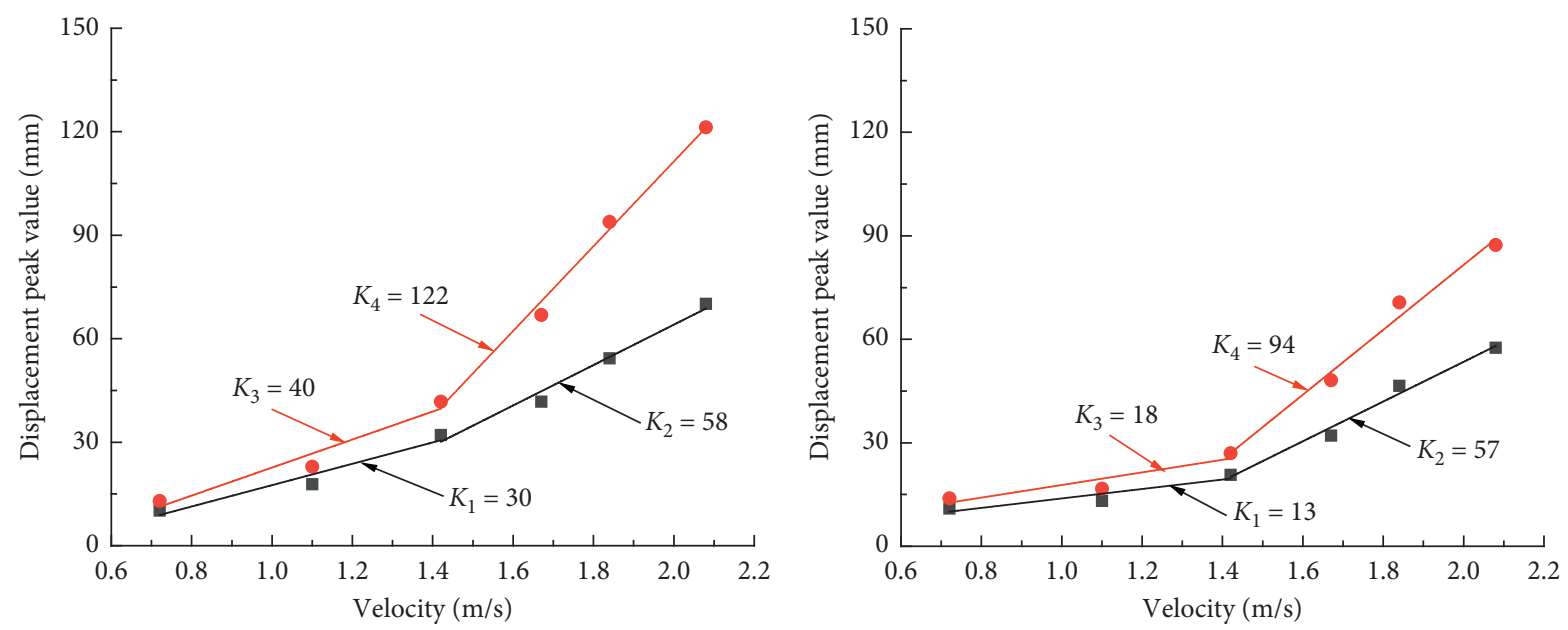
- S1-16
- Z2-16
$\mathrm{S} 1-16-K_{1}=30$ $\left(R^{2}=0.898\right)$

(a)

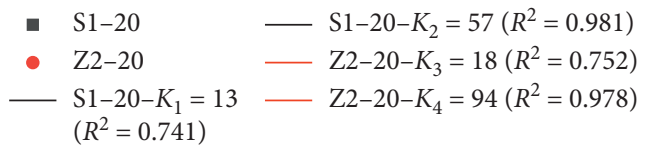

(b)

FIGURE 14: Fitting curve of the top displacements and impact velocities of the first and second groups.

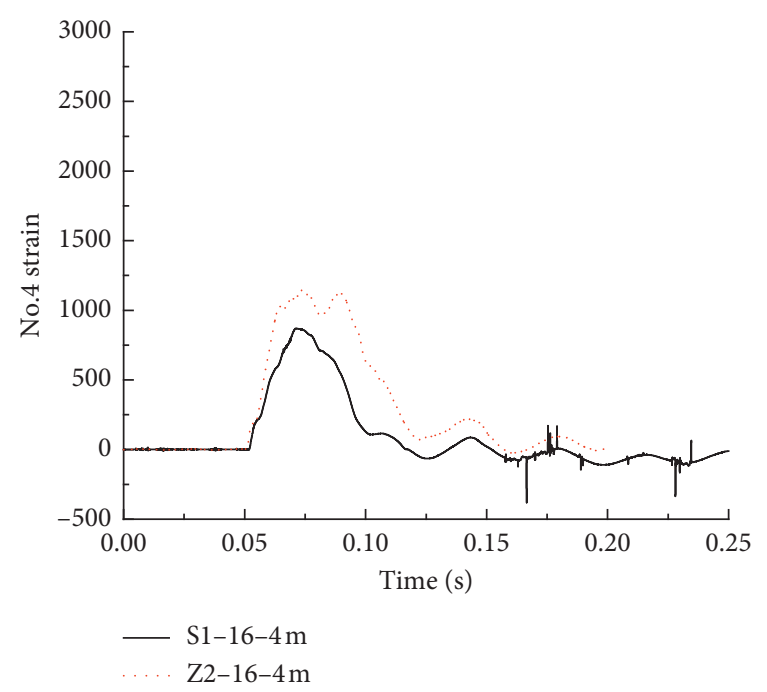

(a)

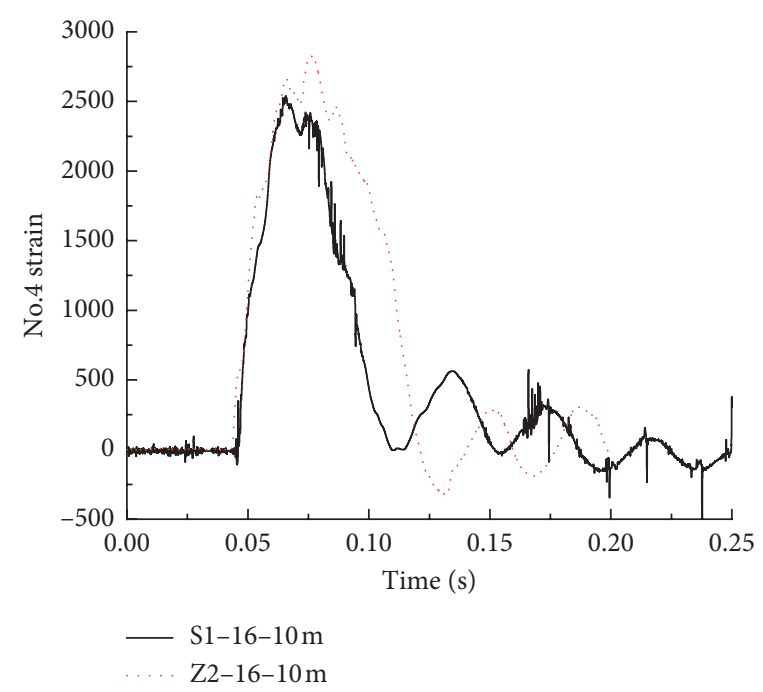

(b)

FIGURE 15: Continued. 


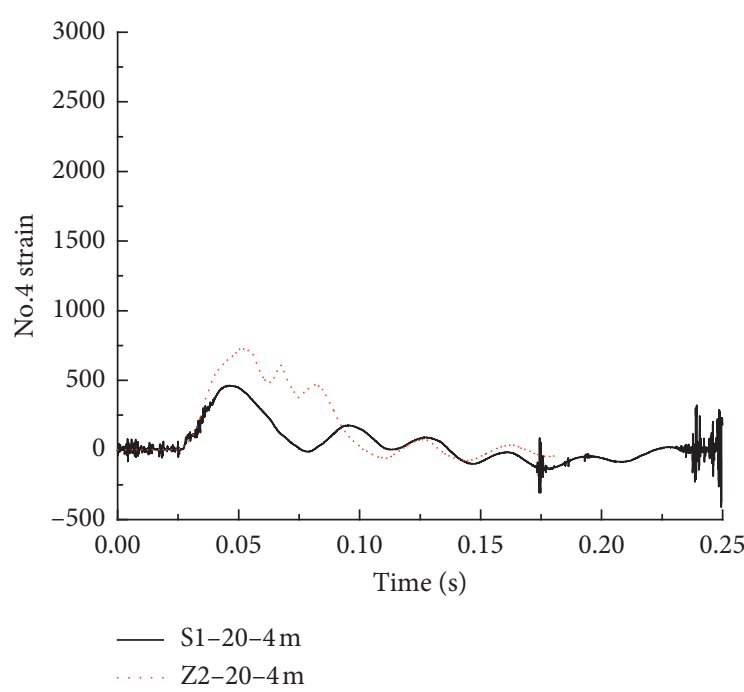

(c)

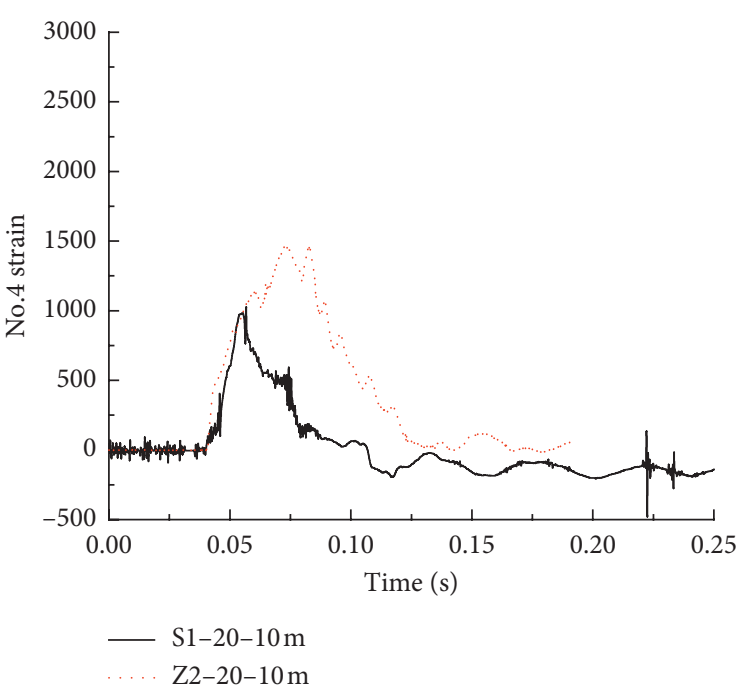

(d)

FIgURE 15: Time history curves of the strain of the No. 4 drop hammer when lifted to $6 \mathrm{~m}$ and $10 \mathrm{~m}$. In the figure, diameter 16 is $50 \mathrm{~mm}$ closed-cell aluminum foam and diameter 20 is $100 \mathrm{~mm}$ closed-cell aluminum foam.

TABLE 8: Test results of the peak strain and stress of the No. 4 reinforcement.

\begin{tabular}{|c|c|c|c|c|c|c|c|c|c|}
\hline \multirow{3}{*}{$\begin{array}{l}\text { Height of drop } \\
\text { hammer }(\mathrm{m})\end{array}$} & \multirow{3}{*}{$\begin{array}{l}\text { Average impact } \\
\text { velocity }(\mathrm{m} / \mathrm{s})\end{array}$} & \multicolumn{4}{|c|}{$1^{\text {st }}$ group } & \multicolumn{4}{|c|}{$2^{\text {nd }}$ group } \\
\hline & & \multicolumn{2}{|c|}{ No. 4 peak $(\mu \varepsilon)$} & \multicolumn{2}{|c|}{ No. 4 stress $(\mathrm{MPa})$} & \multicolumn{2}{|c|}{ No. 4 peak $(\mu \varepsilon)$} & \multicolumn{2}{|c|}{ No. 4 stress $(\mathrm{MPa})$} \\
\hline & & S1-16 & Z2-16 & S1-16 & Z2-16 & S1-20 & $\mathrm{Z} 2-20$ & S1-20 & $\mathrm{Z} 2-20$ \\
\hline 2 & 0.72 & 543.38 & 797.15 & 104.87 & 159.43 & 203.14 & 405.6 & 39.21 & 81.12 \\
\hline 4 & 1.10 & 864.53 & 1159.78 & 166.85 & 231.96 & 460.43 & 735.43 & 78.28 & 147.09 \\
\hline 6 & 1.42 & 1564.35 & 1716.23 & 325.08 & 343.25 & 550.25 & 988.73 & 106.20 & 197.75 \\
\hline 8 & 1.67 & 2314.26 & 2536.65 & 465.95 & - & 652.21 & 1123.45 & 125.88 & 224.69 \\
\hline 10 & 1.84 & 2543.88 & 2872.25 & 516.06 & - & 958.06 & 1473.18 & 184.91 & 294.64 \\
\hline 12 & 2.08 & 2812.34 & 2946.47 & 546.64 & - & 1011.43 & 1896.14 & 195.21 & 379.23 \\
\hline
\end{tabular}

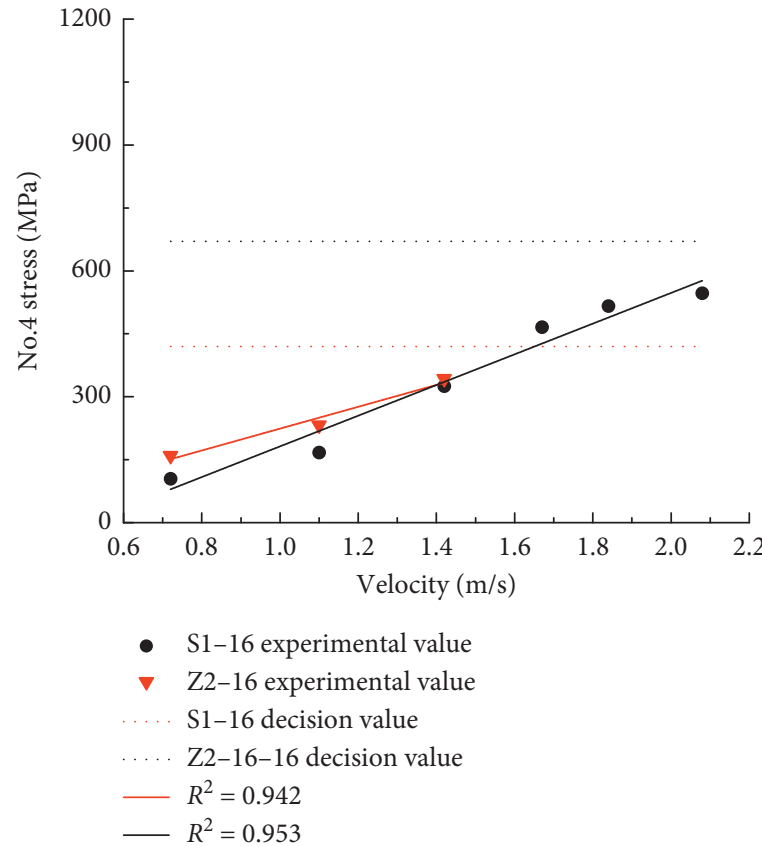

(a)

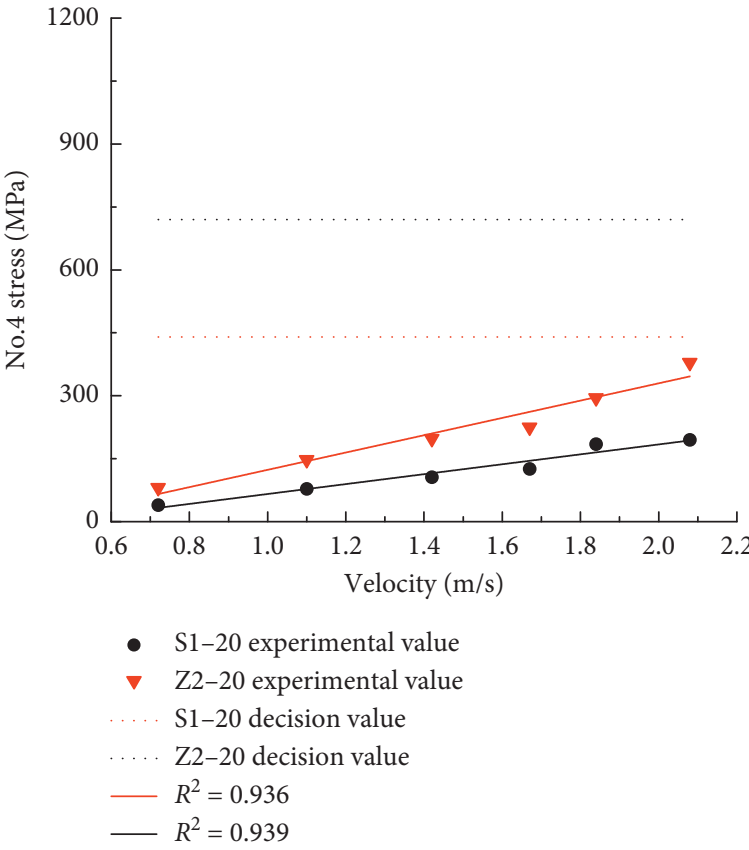

(b)

Figure 16: Fitting of the stress and impact velocity values of the No. 4 reinforcements. In the figure, diameter 16 is $50 \mathrm{~mm}$ closed-cell aluminum foam and diameter 20 is $100 \mathrm{~mm}$ closed-cell aluminum foam; when the Z2-16 reinforcement reached the yield stage at $1.2 \mathrm{~m} / \mathrm{s}$, its elastic modulus could not be determined, and only the first two three values were removed. 
TABLE 9: Changes in the ultrasonic speeds of the concrete.

\begin{tabular}{|c|c|c|c|c|c|c|c|}
\hline \multirow{2}{*}{ Specimen } & \multirow{2}{*}{$\begin{array}{l}\text { Height of drop } \\
\text { hammer }(\mathrm{m})\end{array}$} & \multirow{2}{*}{$\begin{array}{l}\text { Average impact } \\
\text { velocity }(\mathrm{m} / \mathrm{s})\end{array}$} & \multicolumn{2}{|c|}{$\begin{array}{l}\text { Average sound } \\
\text { velocity }(\mathrm{km} / \mathrm{s})\end{array}$} & \multirow{2}{*}{$\begin{array}{l}\text { Reduction of the } \\
\text { sound velocity } \\
(\mathrm{km} / \mathrm{s})\end{array}$} & \multirow{2}{*}{$\begin{array}{l}\text { Total reduction of the } \\
\text { sound velocity }(\mathrm{km} / \mathrm{s})\end{array}$} & \multirow{2}{*}{$\begin{array}{l}\text { Change rate of the } \\
\text { sound velocity (\%) }\end{array}$} \\
\hline & & & $\begin{array}{l}\text { Before } \\
\text { impact }\end{array}$ & $\begin{array}{c}\text { After } \\
\text { impact }\end{array}$ & & & \\
\hline \multirow{6}{*}{ S1-16 } & 2 & 0.72 & 4.323 & 4.305 & 0.018 & \multirow{6}{*}{-0.895} & \multirow{6}{*}{-20.7} \\
\hline & 4 & 1.10 & 4.305 & 4.256 & 0.049 & & \\
\hline & 6 & 1.42 & 4.256 & 4.183 & 0.073 & & \\
\hline & 8 & 1.67 & 4.183 & 4.016 & 0.167 & & \\
\hline & 10 & 1.84 & 4.016 & 3.739 & 0.277 & & \\
\hline & 12 & 2.08 & 3.739 & 3.428 & 0.311 & & \\
\hline \multirow{6}{*}{$Z 2-16$} & 2 & 0.72 & 4.68 & 4.642 & 0.038 & \multirow{6}{*}{-1.784} & \multirow{6}{*}{-38.12} \\
\hline & 4 & 1.10 & 4.642 & 4.579 & 0.063 & & \\
\hline & 6 & 1.42 & 4.579 & 4.489 & 0.09 & & \\
\hline & 8 & 1.67 & 4.489 & 4.175 & 0.314 & & \\
\hline & 10 & 1.84 & 4.175 & 3.579 & 0.596 & & \\
\hline & 12 & 2.08 & 3.579 & 2.896 & 0.683 & & \\
\hline \multirow{6}{*}{ S1-20 } & 2 & 0.72 & 4.031 & 4.018 & 0.013 & \multirow{6}{*}{-0.611} & \multirow{6}{*}{-15.16} \\
\hline & 4 & 1.10 & 4.018 & 3.985 & 0.033 & & \\
\hline & 6 & 1.42 & 3.985 & 3.929 & 0.056 & & \\
\hline & 8 & 1.67 & 3.929 & 3.849 & 0.08 & & \\
\hline & 10 & 1.84 & 3.849 & 3.724 & 0.125 & & \\
\hline & 12 & 2.08 & 3.724 & 3.42 & 0.304 & & \\
\hline \multirow{6}{*}{$\mathrm{Z} 2-20$} & 2 & 0.72 & 4.51 & 4.485 & 0.025 & \multirow{6}{*}{-1.001} & \multirow{6}{*}{-22.2} \\
\hline & 4 & 1.10 & 4.485 & 4.433 & 0.052 & & \\
\hline & 6 & 1.42 & 4.433 & 4.362 & 0.071 & & \\
\hline & 8 & 1.67 & 4.362 & 4.18 & 0.182 & & \\
\hline & 10 & 1.84 & 4.18 & 3.875 & 0.305 & & \\
\hline & 12 & 2.08 & 3.875 & 3.509 & 0.366 & & \\
\hline
\end{tabular}
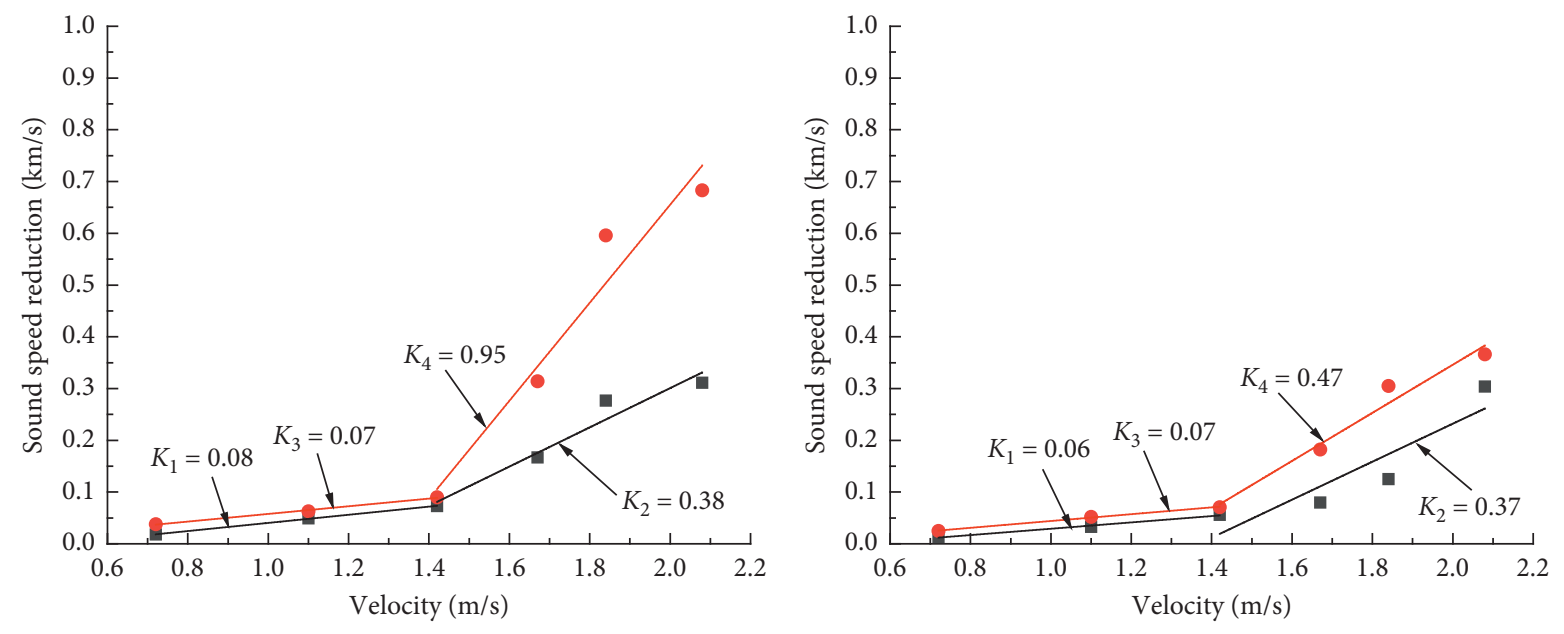

$$
\begin{array}{ll}
\text { - } & \mathrm{S} 1-16 \\
\mathrm{Z} 2-16 & \\
-\mathrm{S} 1-16-K_{1}=0.08\left(R^{2}=0.999\right) \\
\mathrm{S} 1-16-K_{2}=0.38\left(R^{2}=0.919\right) \\
\mathrm{Z} 2-16-K_{3}=0.07\left(R^{2}=0.989\right) \\
\mathrm{Z} 2-16-K_{4}=0.95\left(R^{2}=0.919\right)
\end{array}
$$

(a)

$$
\begin{array}{ll}
\text { - } & \mathrm{S} 1-20 \\
\mathrm{Z} 2-20 & \\
\mathrm{~S} 1-20-K_{1}=0.06\left(R^{2}=0.984\right) \\
\mathrm{S} 1-20-K_{2}=0.07\left(R^{2}=0.743\right) \\
\mathrm{Z} 2-20-K_{3}=0.07\left(R^{2}=0.995\right) \\
\mathrm{Z} 2-20-K_{4}=0.47\left(R^{2}=0.955\right)
\end{array}
$$

(b)

FiguRE 17: Correlation between the ultrasonic speed reductions and the impact speeds. In the figure, diameter 16 is $50 \mathrm{~mm}$ closed-cell aluminum foam and diameter 20 is $100 \mathrm{~mm}$ closed-cell aluminum foam. 
TABLE 10: Development and failure of the final cracks of each specimen.

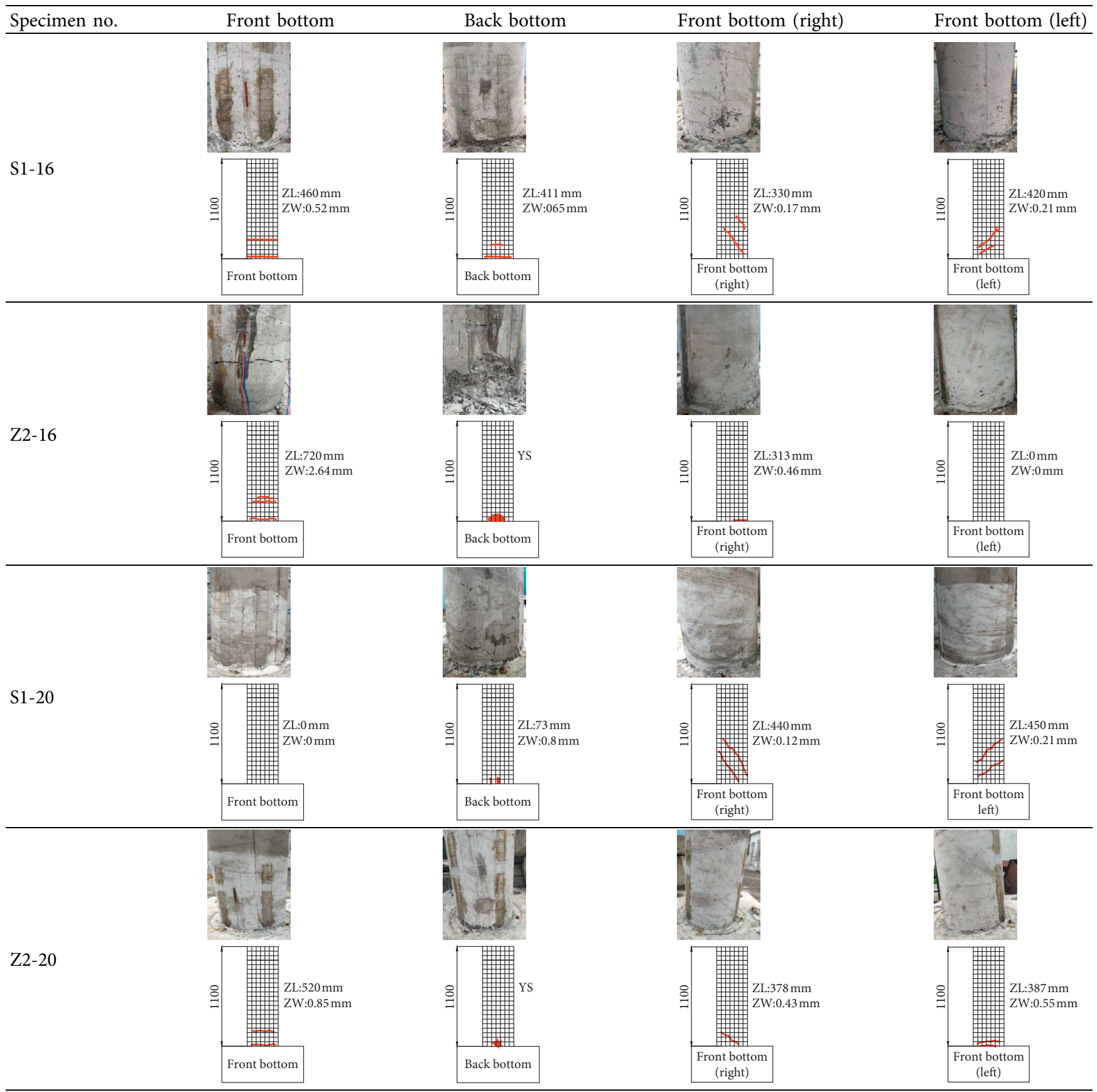

Note. In the table, ZL represents the lengths of the main cracks; ZW represents the widths of the main cracks; and YS represents the crushing of the concrete.

waves increased, which was reflected in the decreases in the sound speed [31-33].

As detailed in Table 8, with the increases in the impact height, the change rates of sound speed had also increased. It was observed that a greater reduction in sound speed indicated a higher degree of damage to the concrete specimens, which could then be used to judge the damage conditions of the reinforced concrete piers. Therefore, from the results displayed in Table 8, it could be concluded that the average change rates of the ultrasonic speeds of specimens S1-16 and Z2-16 were $-20.7 \%$ and $-38.12 \%$, respectively, and that of specimens S1-20 and Z2-20 were $-15.16 \%$ and $-22.2 \%$, respectively. These results confirmed that under the same impact energy and closed-cell foam aluminum buffer layer conditions, the damages sustained by the stainless-steel reinforced concrete bridge piers with replaced equal crosssections were less than those of the ordinary reinforced concrete bridge piers.

In order to further understand the damages to each specimen with the changes in the impact speeds, the ultrasonic sound speed reductions and impact speed measurements of each specimen were analyzed. A correlation 
TABLE 11: Quantity, lengths, and maximum widths of the cracks in the lower frontal areas of the specimens under the conditions of different energy force values.

\begin{tabular}{|c|c|c|c|c|c|c|c|c|c|c|c|c|}
\hline \multirow{3}{*}{$\begin{array}{l}\text { Height of drop } \\
\text { hammer }(\mathrm{m})\end{array}$} & \multicolumn{6}{|c|}{$1^{\text {st }}$ group } & \multicolumn{6}{|c|}{$2^{\text {nd }}$ group } \\
\hline & \multicolumn{2}{|c|}{$\begin{array}{c}\text { Number of } \\
\text { cracks }\end{array}$} & \multicolumn{2}{|c|}{$\begin{array}{l}\text { Lengths of the } \\
\text { main cracks } \\
(\mathrm{mm})\end{array}$} & \multicolumn{2}{|c|}{$\begin{array}{l}\text { Widths of the } \\
\text { main cracks } \\
(\mathrm{mm})\end{array}$} & \multicolumn{2}{|c|}{$\begin{array}{c}\text { Number of } \\
\text { cracks }\end{array}$} & \multicolumn{2}{|c|}{$\begin{array}{l}\text { Lengths of the } \\
\text { main cracks } \\
\text { (mm) }\end{array}$} & \multicolumn{2}{|c|}{$\begin{array}{l}\text { Widths of the } \\
\text { main cracks } \\
(\mathrm{mm})\end{array}$} \\
\hline & $\mathrm{S} 1-16$ & Z2-16 & S1-16 & Z2-16 & S1-16 & Z2-16 & $\mathrm{S} 1-20$ & $\mathrm{Z} 2-20$ & $\mathrm{~S} 1-20$ & $\mathrm{Z} 2-20$ & $\mathrm{~S} 1-20$ & $\mathrm{Z} 2-20$ \\
\hline 2 & 0 & 0 & 0 & 0 & 0 & 0 & 0 & 0 & 0 & 0 & 0 & 0 \\
\hline 4 & 0 & 0 & 0 & 0 & 0 & 0 & 0 & 0 & 0 & 0 & 0 & 0 \\
\hline 6 & 0 & 0 & 0 & 0 & 0 & 0 & 0 & 0 & 0 & 0 & 0 & 0 \\
\hline 8 & 0 & 1 & 0 & 446.3 & 0 & 0.70 & 0 & 0 & 0 & 0 & 0 & 0 \\
\hline 10 & 1 & 3 & 400 & 595.0 & 0.15 & 2.15 & 1 & 1 & 380 & 220 & 0.11 & 0.5 \\
\hline 12 & 2 & 4 & 460 & 720 & 0.52 & 2.64 & 2 & 2 & 450 & 520 & 0.2 & 0.85 \\
\hline
\end{tabular}

diagram of the ultrasonic sound speed reductions and impact speeds was achieved, as shown in Figure 17.

It can be seen in Figure 17 that prior to the impact speeds reaching $1.42 \mathrm{~m} / \mathrm{s}$, the change rates of the ultrasonic speed reductions were relatively gentle. However, after the impact speeds had exceeded $1.42 \mathrm{~m} / \mathrm{s}$, the ultrasonic speed reduction rates were observed to sharply increase. The obtained results clearly showed that before the yield stage, the aluminum foam had achieved good protection results for the piers. However, with the accumulation of impact energy, the dense closed-cell aluminum foam had negative impacts on the piers. In fact, it was found to increase the damage levels of the piers, which was evident in the impact force and displacement values. It was observed that at the same height, before and after the impacts, the change rates of the sound velocity of the ordinary reinforced concrete specimens were slightly larger than those of the stainless-steel reinforced concrete specimens. It was noted that to some extent, the results could be explained by the fact that the damage degrees of the ordinary reinforced concrete specimens after each impact were larger than those of the stainless-steel reinforced concrete specimens. This was determined to be mainly related to the high strength and toughness characteristics of the stainless-steel bars when compared with the ordinary steel bars. As a result, the stainless-steel reinforced concrete piers had shown better impact deformation resistance abilities.

3.5. Fracture Development and Failure Modes. In the current experimental study, it was observed that cracks appeared at the bottom of the impacted surfaces among the two groups of specimens. The cracks then grew and expanded with the increases in the impact heights. For example, when the impact height reached a certain degree, large cracks appeared at the bottoms of the impacted frontal areas, and sections of the concrete at the bottom of the impacted back areas were crushed. In addition, a small portion of the concrete was observed to be crushed at the impact points in the middle of the affected frontal areas. However, the cracks were not obvious. In addition, small cracks appeared in the middle of the impacted back areas of the samples. The final crack development and failure process of each sample are detailed in Table 10.
It can be seen in Table 10 that there were horizontal cracks at the bottom frontal area of column S1-16, as well as concrete crushing at the bottom of the back section. It was found that with the increases in the impact height, several small diagonal cracks had occurred at the sides of the columns, which extended to the impact position at approximately 45 degrees. In addition, the failure mode had changed from the initial bending failure to bending shear failure. Furthermore, there were horizontal cracks observed at the front of the Z2-16 columns in the bottom regions, and concrete crushing had occurred at the bottoms of the back areas. The failure mode was determined to mainly be bending failure. The obtained results revealed that under the same impact energy conditions, the failure mode of the two specimens were different before and after the replacement of the stainless-steel equal cross-sections. The stainless-steel reinforced concrete bridge piers had displayed a brittle shear failure mode, while the ordinary reinforced concrete bridge piers displayed a ductile bending failure mode. These different failure modes were mainly due to the fact that the stainless-steel bars had higher strength and toughness characteristics when compared with the ordinary steel bars. It was observed that in the same reinforcement ratio, the section resistance moments of the stainless-steel reinforced concrete piers were much higher than those of the ordinary concrete, which had resulted in the bending failure of the ordinary reinforced concrete piers and the bending shear failure of the stainless-steel reinforced concrete piers. Table 10 details the quantities, lengths, and maximum widths of cracks in the lower frontal areas of the test pieces under the conditions of different energy force values.

It can be seen in Table 11 that when the impact speed was low, the closed-cell aluminum foam had displayed the ability to effectively reduce the impact damages. However, when the impact speed was higher, the impact damages of the components had displayed a certain correlation with the impact failure modes of the components.

\section{Conclusions}

In this research study, comparisons and experimental examinations of the horizontal impacts of two groups of specimens with equal cross-section replacements in reinforced concrete bridge piers were carried out under the buffering conditions of closed-cell aluminum foam 
applications. This study analyzed the impact force time history and displacement time history of the specimens, as well as the reinforcement strain time history, concrete damages, and crack evolution of the reinforced concrete bridge piers under different impact speeds, impact energy forces, and multiple impacts. The main conclusions were as follows:

(1) Under the same impact energy, the impact forces of the stainless-steel reinforced piers were found to be greater than that of the ordinary reinforced concrete piers. When the closed-cell aluminum foam was in an elastic or yield stage, it was able to effectively reduce the impact effects on the outside areas on the piers, and the peak impact force ratios were determined to be stable at approximately $28 \%$ and $34 \%$, respectively, for the two groups of specimens. However, when the closed-cell foam rate entered the densification stage, the peak impact force ratios decreased sharply for the two specimen groups, from $34 \%$ to $8 \%$ and from $28 \%$ to $5 \%$, respectively. It was observed that the densification of the closed-cell aluminum foam had more influence on the ordinary reinforced concrete members than on the stainlesssteel reinforced concrete members.

(2) In the present study, it was found that when the impact velocity was low (for example, less than $1.42 \mathrm{~m} / \mathrm{s}$ ), the closed-cell aluminum foam was in either an elastic stage or yield stage, and the closedcell aluminum foam could effectively protect the reinforced concrete components. For example, the relative ratios of the top displacements of the two groups of pier components were observed to be stable at approximately $22 \%$, and the change rates of the concrete ultrasonic damages were approximately the same. It was also observed that when the impact velocity was large (for example, more than $1.67 \mathrm{~m} / \mathrm{s}$ ), the effective energy absorption abilities of the aluminum foam had gradually been reduced. It was determined that this was the result of the gradual densification of aluminum foam and its increased stiffness, which had accelerated the damages to the concrete piers. For example, the relative ratios of the peak displacements at the tops of the components showed increasing trends (from $22 \%$ to $42 \%$ and from $22 \%$ to $34 \%$ for the two groups, respectively). Therefore, the change rates of the concrete ultrasonic damages had changed significantly.

(3) Under the same impact energy, the stainless-steel reinforced concrete pier has better impact resistance than the ordinary concrete pier before and after the replacement of stainless steel with a constant crosssection, i.e., it has smaller overall bending and deformation, and a higher energy absorption capacity.

(4) In the current study, it was observed that prior to and after the equal cross-section replacements of stainless-steel bars, the failure modes of the two groups of specimens had differed. The main failure mode of the stainless-steel reinforced concrete piers was determined to be shear failure. Meanwhile, that of ordinary reinforced concrete piers was confirmed to be bending shear failure. For example, the strain values and crack formation of the steel bars had proven that the Z2-20 specimen had experienced bending shear failure and the S1-20 specimen had undergone shear failure, which were mainly caused by the fact that stainless-steel bars had the advantages of higher strength and toughness when compared with the ordinary steel bars. Moreover, the section resistance moments of the stainless-steel reinforced concrete piers were much higher than those of the ordinary concrete following the equal cross-section replacement procedures.

\section{Data Availability}

We verify that all our test data are accurate and reliable. The test data are included within the article and can be made freely available.

\section{Conflicts of Interest}

The authors declare that there are no conflicts of interest regarding the publication of this paper.

\section{Acknowledgments}

The research described in this paper was sponsored by the Major Project (Natural Science) of the Department of Education of Guangdong Province (2014KZDXM064), the Science and Technology Innovation Project of the Department of Education of Guangdong Province (2013KJCX0188), and the Civil Engineering Technology Research Center of Guangdong Province.

\section{References}

[1] J. Pan, H. Fang, Y. Wu et al., "Numerical analysis on the impact performance of composite energy absorption structure of bridge pier against vehicle collision," Huazhong Keji Daxue Xuebao (Ziran KexueBan)/Journal of Huazhong University of Science and Technology (Natural Science Edition), vol. 46, no. 8 , pp. 122-127, 2018 .

[2] T. Dai and N. Wu, "Overview of the vessel bump bridge accident," Communications Science and Technology Heilongjiang, vol. 2, pp. 1-3, 2003.

[3] F. Goerlandt and P. Kujala, "On the reliability and validity of ship-ship collision risk analysis in light of different perspectives on risk," Safety Science, vol. 62, pp. 348-365, 2014.

[4] S. El-Tawil, E. Severino, and P. Fonseca, "Vehicle collision with bridge piers," Journal of Bridge Engineering, vol. 10, no. 3, pp. 345-353, 2005.

[5] H. Sharma, S. Hurlebaus, and P. Gardoni, "Performancebased response evaluation of reinforced concrete columns subject to vehicle impact," International Journal of Impact Engineering, vol. 43, pp. 52-62, 2012.

[6] I. Thilakarathna, D. Thambiratnam, M. Dhanasekar et al., "Shear-critical impact response of biaxially loaded reinforced 
concrete circular columns," ACI Structural Journal, vol. 110, no. 4, pp. 565-574, 2013.

[7] J. Pan, H. Fang, M. Cai Xu, and Y. Feng Wu, "Study on the performance of energy absorption structure of bridge piers against vehicle collision," Thin-Walled Structures, vol. 130, pp. 85-100, 2018.

[8] M.-s. Qi, J.-n. Zhang, W. Yang et al., "Research on shock cushing performance of foamed aluminium polyurethane composite structure," Packaging Engineering, vol. 31, no. 19, pp. 6-9, 2010.

[9] W. Jiang and L. Zhan-fang, "Porous hypereastic model for foam packaging material," Packaging Engineering, vol. 29, no. 3, pp. 27-29, 2008.

[10] C. L. Shan and X. J. Xu, "Analysis of mechanical properties of pier anti-collision device by sandwich plate with overall curved surface," Zhongguo Gonglu Xuebao/China Journal of Highway and Transport, vol. 27, no. 10, pp. 46-54, 2014.

[11] J. Ge, C. Jiang, G. Jun Yu, B. Su, and T. Sun, "Preparation and research on a kind of magnetorheological grease materiel used anti-collision system," Materials Science Forum, vol. 893, pp. 395-399, 2017.

[12] R. Suter, "Reinforcement of bridge piers with FRP sheets to resist vehicle impact," IABSE Symposium Report, vol. 90, no. 9, pp. 125-130, 2005.

[13] K. Fujikake, B. Li, and S. Soeun, "Impact response of reinforced concrete beam and its analytical evaluation," Journal of Structural Engineering, vol. 135, no. 8, pp. 938-950, 2009.

[14] H.-H. Tsang and N. T. K. Lam, "Collapse of reinforced concrete column by vehicle impact," Computer-Aided Civil and Infrastructure Engineering, vol. 23, no. 6, pp. 427-436, 2010.

[15] H. Sharma, S. P. Gardoni, and S. Hurlebaus, "Probabilistic demand model and performance-based fragility estimates for RC column subject to vehicle collision," Engineering Structures, vol. 74, pp. 86-95, 2014.

[16] O. I. Abdelkarim and M. A. Elgawady, "Performance of bridge piers under vehicle collision," Engineering Structures, vol. 140, pp. 337-352, 2017.

[17] Z. Xiaoyu, M. A. Rujin, and C. Airong, "Anti-shear reliability analysis for a reinforced concrete column subjected to rockfall impact," Journal of Vibration and Shock, vol. 36, no. 7, pp. 262-270, 2017.

[18] X. Zhou, Y. Gao, G. Zhang, and S. Xu, "An experimental research of mechanical properties of the impacts of equalstrength stainless reinforced replacement piers," Advance in Mechanical Engineering, vol. 10, 2018.

[19] L. Tian, C. Zhu, H. Wang et al., "Dynamic response and failure modes OF RC columns under impact," Engineering $\mathrm{Me}$ chanics, vol. 30, no. 2, pp. 150-155, 2013.

[20] J. Huo and K. Hu, "Failure mechanism of RC beams under impact loading and discussion on prediction methods of residual deflection," Hunan Daxue Xuebao/Journal of Hunan University Natural Ences, vol. 44, no. 1, pp. 112-117, 2017.

[21] D. Bozzolo and R. Pamini, "Simulation of rock falls down a valley side," Acta Mechanica, vol. 63, no. 1-4, pp. 113-130, 1986.

[22] Y. Hangai, H. Kato, T. Utsunomiya, S. Kitahara, O. Kuwazuru, and N. Yoshikawa, "Effects of porosity and pore structure on compression properties of blowing-agent-free aluminum foams fabricated from aluminum alloy die castings," Materials Transactions, vol. 53, no. 8, p. 1515, 2012.

[23] D. P. Mondal, M. D. Goel, and S. Das, "Compressive deformation and energy absorption characteristics of closed cell aluminum-fly ash particle composite foam," Materials Science
\& Engineering: A (Structural Materials: Properties, Microstructure and Processing), vol. 507, no. 1-2, pp. 102-109, 2009.

[24] R. E. Raj, V. Parameswaran, and B. S. S. Daniel, "Comparison of quasi-static and dynamic compression behavior of closed-cell aluminum foam," Materials Science \& Engineering: A (Structural Materials: Properties, Microstructure and Processing), vol. 526, no. 1-2, pp. 11-15, 2009.

[25] A. Paul and U. Ramamurty, "Strain rate sensitivity of a closedcell aluminum foam," Materials Science and Engineering: A, vol. 281, no. 1-2, pp. 1-7, 2000.

[26] J. W. Klintworth and W. J. Stronge, "Elasto-plastic yield limits and deformation laws for transversely crushed honeycombs," International Journal of Mechanical Sciences, vol. 30, no. 3-4, pp. 273-292, 1988.

[27] A. E. Simone and L. J. Gibson, "The effects of cell face curvature and corrugations on the stiffness and strength of metallic foams," Acta Materialia, vol. 46, no. 11, pp. 3929-3935, 1998.

[28] C. Zhu, Dynamic Response and Damage Mechanism of Reinforced Concrete Structures Under Crash, Tianjin University, Tianjin, China, 2012.

[29] Y. Wu, S. HE, L. Xinpo, C. Ouyang, Y. Jiang, and D. Wang, "Study on elliptic anti rock-fall impact structure with double energy dissipation layers wrapping up pier eccentrically in mountains," Engineering Mechanics, vol. 34, no. 10, pp. 158167, 2017.

[30] Q. M. Li, I. Magkiriadis, and J. J. Harrigan, "Compressive strain at the onset of densification of cellular solids," Journal of Cellular Plastics, vol. 42, no. 5, pp. 371-392, 2006.

[31] P. Daponte, R. S. F. Maceri, and R. S. Olivito, "Ultrasonic signal-processing techniques for the measurement of damage growth in structural materials," IEEE Transactions on Instrumentation and Measurement, vol. 44, no. 6, pp. 10031008, 1995.

[32] R. Bairrao, J. M. Chrzanowski, and P. Latus, "Ultrasonic damage measurement in reinforced concrete beams," Damage Assessment of Structures VI, vol. 293-294, pp. 695-702, 2005.

[33] H. J. Yim, J. H. Kim, and H. G. Kwak, "Ultrasonic wave attenuation measurement for nondestructive evaluation of concrete," Proceedings of SPIE, vol. 7649, no. 1, 2010. 